Article

\title{
Synthesis, Evaluation, and Mechanism Study of New Tepotinib Derivatives as Antiproliferative Agents
}

\author{
Niu-niu Zhang $(\mathbb{D}$, Bai-jiao An, Yan Zhou, Xing-shu Li * and Ming Yan *(D) \\ Institute of Drug Synthesis and Pharmaceutical Process, School of Pharmaceutical Sciences, Sun Yat-sen \\ University, Guangzhou 510006, China; zhangniuniuu@yeah.net (N.-n.Z.); 15521085401@163.com (B.-j.A.); \\ zhouy598@mail2.sysu.edu.cn (Y.Z.) \\ * Correspondence: lixsh@mail.sysu.edu.cn (X.-s.L.); yanming@mail.sysu.edu.cn (M.Y.); \\ Tel.: +86-137-2676-2798 (X.-s.L.); +86-136-4087-9357 (M.Y.)
}

Academic Editor: Jean Jacques Vanden Eynde

Received: 16 February 2019; Accepted: 20 March 2019; Published: 25 March 2019

\begin{abstract}
Inspired by the potent inhibition activity of the c-Met (mesenchymal-epithelial transition factor) inhibitor Tepotinib, a series of new Tepotinib derivatives were synthesized and evaluated for their ability to act as antiproliferative agents to find the leading compounds with good activity and limited side effects. Among them, compound 31e exhibited potent antiproliferative activity $\left(\mathrm{IC}_{50}\right.$ $(50 \%$ inhibitory concentration $)=0.026 \mu \mathrm{M})$ against hepatic carcinoma $97 \mathrm{H}$ (human liver cancer cell) cells and, importantly, had very low inhibitory activity against normal cells. A mechanism study demonstrated that 31e induced G1 phase (First growth phase or G indicating gap) arrest, inhibited the phosphorylation of c-Met and its downstream signaling component, Akt (Protein Kinase B), and also inhibited the migration of hepatic carcinoma $97 \mathrm{H}$ cells.
\end{abstract}

Keywords: antiproliferative agents; c-Met inhibitor; 97H cells; low toxicity

\section{Introduction}

Cancer is a major disease that seriously threatens human health. According to statistics from the World Health Organization (WHO), an estimated 9.6 million patients died from cancer in 2018 [1]. Therefore, the development of effective anti-tumor drugs is an important task for medicinal chemists. Mesenchymal-epithelial transition factor (c-Met), the high affinity receptor for hepatocyte growth factor (HGF), is a unique subfamily of receptor tyrosine kinases (RTKs) [2]. Physiologically, HGF/c-Met signaling plays important roles in cell growth, survival, motility, and morphogenesis [3]. However, aberrant c-Met activation has been observed in a wide variety of human cancers, including liver and lung cancer, as a consequence of gene amplification or rearrangement, transcriptional regulation, as well as autocrine or paracrine ligand stimulation [4-9]. Due to its status as a proto-oncogene and the correlation of its dysregulation with a poor prognosis, c-Met is becoming a promising target for cancer therapy [10]. The present c-Met kinase inhibitors are divided into three groups according to their binding modes and structural features. Type I c-Met kinase inhibitors, such as Crizotinib A, are adenosine triphosphate (ATP)-competitive inhibitors with a U-shaped binding mode at the ATP binding site (Figure 1) [11,12]. Type II c-Met kinase inhibitors are usually multi-targeted agents (for example, Cabozantinib B) (Figure 1) [13]. Type I inhibitors are generally described as specific for c-Met kinase and more selective than class II inhibitors. However, they have limited activity against the Tyr1230His mutation that is present in certain human tumors [4]. Type III inhibitors include other atypical c-Met kinase inhibitors, such as Tivantinib C (Figure 1) [14]. 


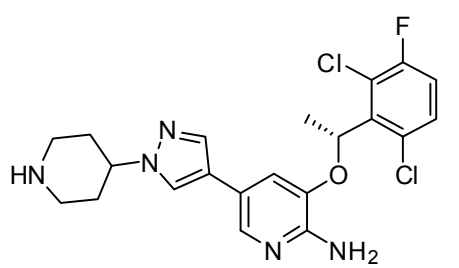

Crizotinib A

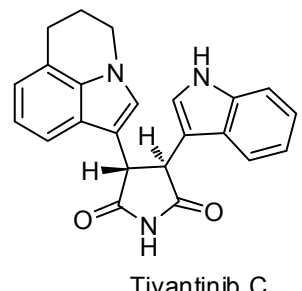<smiles>COc1cc2nccc(Oc3ccc(NC(=O)C4(C(=O)Nc5ccc(F)cc5)CC4)cc3)c2cc1OC</smiles>

Cabozantinib B<smiles>CN1CCC(COc2cnc(-c3cccc(Cn4nc(-c5cccc(C#N)c5)ccc4=O)c3)nc2)CC1</smiles>

Tepotinib D

Figure 1. The representative c-Met kinase inhibitors of different structural types.

In 2015, Dorsch et al. reported optimized pyridazinones as being potent and selective c-Met kinase inhibitors [15]. We found that the optimal compound, Tepotinib D (Figure 1), displays excellent in vitro potency and in vivo anti-tumor efficacy at low doses. According to the co-crystal structure of Tepotinib D with c-Met, it belongs to the type I c-Met kinase inhibitors. The review by Manjunath D. Ghate et al. described the recent advances of small molecule c-Met kinase inhibitors, including several pyridazinone derivatives, but the similar structures of our compounds have not been reported before [16]. Inspired by the interesting scaffold of Tepotinib, we decided to synthesize and evaluate new Tepotinib derivatives to find leading compounds with good activity and limited side effects.

Our design is shown in Figure 2 and includes the following steps: (a) Changing the position of nitrogen on the pyridazinone ring to provide pyrazin-2(1H)-one and pyrimidin-2(1H)-one derivatives for the study of the structure-activity relationships; (b) evaluating the anti-tumor activity of the derivatives with or without alkyl substitution on the methylene group; (c) examining the effect of fluorine substitution on pyridin-2(1H)-one on the anti-tumor activity; and (d) investigating the effect of side chains on the activity. Herein, we reported the synthesis, evaluation, and optimization of new Tepotinib derivatives as anti-tumor agents.

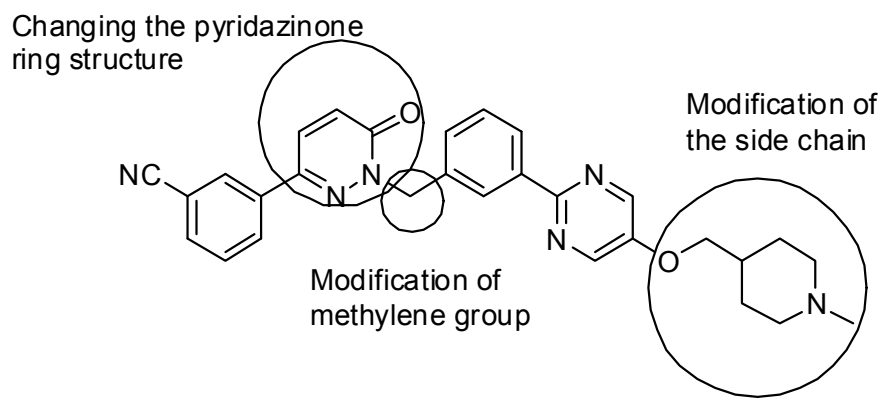

Figure 2. Design of new Tepotinib derivatives.

\section{Results}

\subsection{Chemistry}

The synthesis of target compounds $\mathbf{1 1 a}$ and $\mathbf{1 1} \mathbf{b}$ is summarized in Scheme 1 . The conventional Suzuki coupling reaction of (3-(hydroxymethyl)phenyl)boronic acid and 2-chloro-5-fluoropyrimidine catalyzed with $\mathrm{PdCl}_{2}\left(\mathrm{PPh}_{3}\right)_{2}$ gave (3-(5-fluoropyrimidin-2-yl)phenyl)methanol 5 with 
a yield of $68 \%$. Chlorination of 5 in the presence of thionyl chloride provided 2-(3-(chloromethyl)phenyl)-5-fluoropyrimidine 6. On the other hand, the oxidation of ketones 1a or $\mathbf{1 b}$ followed by cyclization provided $\mathbf{2 a}$ and $\mathbf{2 b}$ [17], which reacted with compound $\mathbf{6}$ to give $\mathbf{7 a}$ and $\mathbf{7 b}$. Compound 10 was synthesized by the reaction of $\mathbf{8}$ and $\mathbf{9}$. Finally, compounds $11 \mathrm{a}$ and $\mathbf{1 1 b}$ were prepared by the reaction of $\mathbf{7 a}, \mathbf{7 b}$, and $\mathbf{1 0}$ under alkaline conditions.

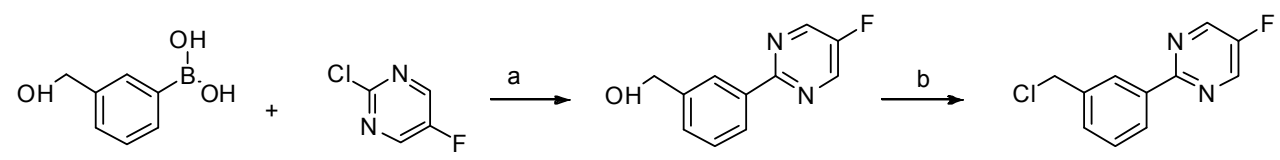

3

4

5

6

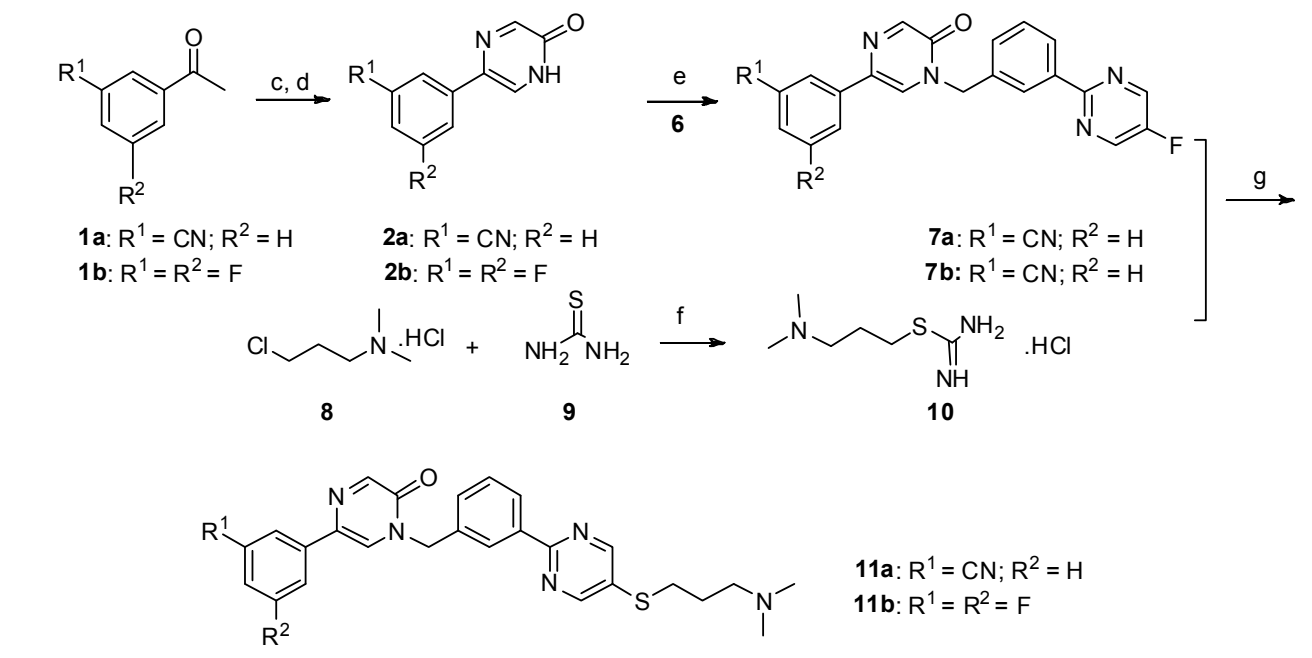<smiles>[R]c1cc([R])cc(-c2cn(Cc3cccc(-c4ncc(SCCCN(C)C)cn4)c3)c(=O)cn2)c1</smiles>
(1)

Scheme 1. Reagents and conditions: a) $\mathrm{PdCl}_{2}\left(\mathrm{PPh}_{3}\right)_{2}, \mathrm{Na}_{2} \mathrm{CO}_{3}$, ethanol/toluene/water, $90^{\circ} \mathrm{C}, 8 \mathrm{~h}$; b) $\mathrm{SOCl}_{2}, \mathrm{CHCl}_{3}$, reflux; c) $\mathrm{SeO}_{2}$, dioxane: $\mathrm{H}_{2} \mathrm{O}=10: 1$, reflux, $12 \mathrm{~h}$; d) $\mathrm{NaOH},-30^{\circ} \mathrm{C}$; e) $\mathrm{NaH}, \mathrm{DMF} / \mathrm{THF}$, $0{ }^{\circ} \mathrm{C}$-room temperature, $12 \mathrm{~h}$; f) dry ethanol, reflux; g) $\mathrm{NaOH}, \mathrm{DMF} / \mathrm{H}_{2} \mathrm{O}, 60^{\circ} \mathrm{C}, 8 \mathrm{~h}, \mathrm{~N}_{2}$.

The synthesis of compounds 18, 22, and 25 is shown in Scheme 2. $\mathrm{CH}_{3} \mathrm{OCH}_{2}$-protected 5-bromopyrimidin-2-ol 14 reacted with (3-cyanophenyl)boronic acid to provide 15, which was converted to 16 in the presence of $10 \%$ hydrogen chloride. Compound 16 reacted with intermediate 6 to provide 3-(1-(3-(5-fluoropyrimidin-2-yl)benzyl)-2-oxo-1. 2-dihydropyrimidin-5-yl)benzonitrile 17, which reacted with 10 to give target compound 18. Compound 22 was synthesized from 19 via the Mitsunobu reaction and Suzuki coupling reaction. The reductive amination of 23 with formaldehyde and sodium borohydride gave compound 24, which reacted with compound 16 under alkaline conditions to provide compound 25. 
<smiles>CCCOCOc1ncc(Br)cn1</smiles><smiles>CN(C)CCCSc1cnc(-c2cccc(Cn3cc(-c4cccc(C#N)c4)cnc3=O)c2)nc1</smiles><smiles>[Z]OCCCN(C)CC1CCN(C(=O)OCc2ccccc2)CC1</smiles><smiles>CN(C)CCCOc1cnc(-c2cccc(Cn3cc(-c4cccc(C#N)c4)cnc3=O)c2)cn1</smiles>

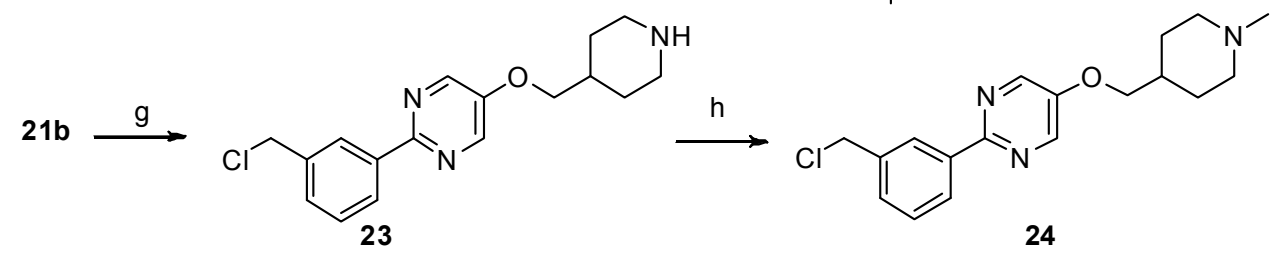<smiles>CN1CCC(COc2cnc(-c3cccc(Cn4cc(-c5cccc(C(C)(C)C)c5)cnc4=O)c3)nc2)CC1</smiles>

Scheme 2. Reagents and conditions: a) $\mathrm{N}, \mathrm{N}$-diisopropylethylamine, dry $\mathrm{CH}_{2} \mathrm{Cl}_{2}, 0{ }^{\circ} \mathrm{C}$-room temperature, $6 \mathrm{~h}$; b) $\mathrm{PdCl}_{2}\left(\mathrm{PPh}_{3}\right)_{2}, \mathrm{Na}_{2} \mathrm{CO}_{3}$, ethanol/toluene/water, $90{ }^{\circ} \mathrm{C}, 8 \mathrm{~h}$; c) $10 \%$ aq. $\mathrm{HCl}$, $\mathrm{MeOH}$, reflux; d) $\mathrm{K}_{2} \mathrm{CO}_{3}$, dry DMF, $80{ }^{\circ} \mathrm{C}, 12 \mathrm{~h}$; e) $\mathrm{NaOH}, \mathrm{DMF} / \mathrm{H}_{2} \mathrm{O}, 60{ }^{\circ} \mathrm{C}, 8 \mathrm{~h}, \mathrm{~N}_{2}$; f) $\mathrm{PPh}_{3}, \mathrm{DIAD}$, $\mathrm{THF}, 0{ }^{\circ} \mathrm{C}$-room temperature; g) $\mathrm{SOCl}_{2}, \mathrm{CHCl}_{3}$, reflux; h) $35 \%$ formaldehyde, $\mathrm{NaBH}_{4}, \mathrm{MeOH}$.

The synthesis of compounds $\mathbf{3 1 a}-\mathbf{g}$ is summarized in Scheme 3. Intermediate $\mathbf{2 7}$ was prepared by the Suzuki coupling reaction of (3-acetylphenyl)boronic acid and 2-chloro-5-fluoropyrimidine. The reduction of compound 27 with sodium borohydride and then chlorination with thionyl chloride produced 29. In the presence of potassium carbonate, 29 reacted with compound 16 to give $30 \mathrm{a}$, which reacted with the corresponding amino alcohols or amino thiols to produce target compounds 31a-f (the R and S configurations of 31e were prepared and are shown in the supporting information). The fluorine-containing target compound $\mathbf{3 1 g}$ was prepared with a similar procedure, starting from compound 14 and intermediate $30 \mathrm{~b}$. 

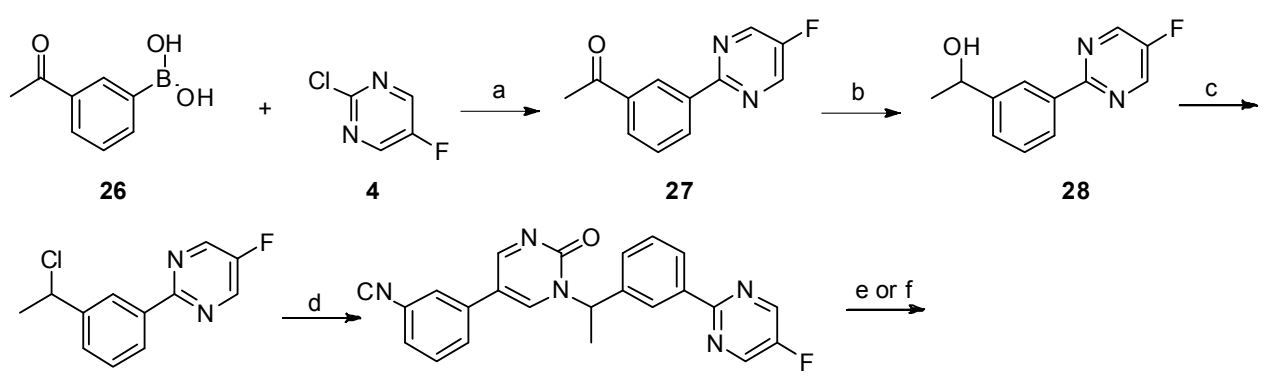

29<smiles>[Z]c1cnc(-c2cccc(C(C)n3cc(-c4cccc(C)c4)cnc3=O)c2)nc1</smiles>

30a
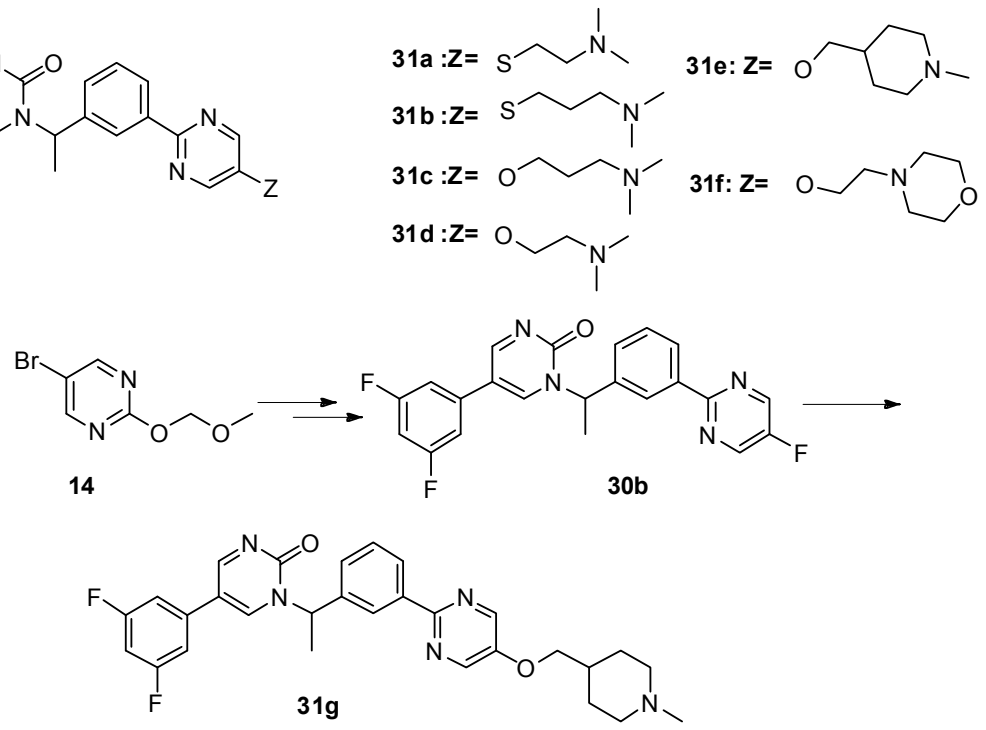

Scheme 3. Reagents and conditions: a) $\mathrm{PdCl}_{2}\left(\mathrm{PPh}_{3}\right)_{2}, \mathrm{Na}_{2} \mathrm{CO}_{3}$, ethanol/toluene/water, $90{ }^{\circ} \mathrm{C}, 8 \mathrm{~h}$; b) $\mathrm{NaBH}_{4}, \mathrm{MeOH}, 0^{\circ} \mathrm{C}$-room temperature, $1 \mathrm{~h}$; c) $\mathrm{SOCl}_{2}, \mathrm{CHCl}_{3}$, reflux; d) $\mathrm{K}_{2} \mathrm{CO}_{3}$, dry DMF, $80{ }^{\circ} \mathrm{C}, 12 \mathrm{~h}$; e) 31a-31b: $\mathrm{NaOH}, \mathrm{DMF} / \mathrm{H}_{2} \mathrm{O}, 60{ }^{\circ} \mathrm{C}, 8 \mathrm{~h}, \mathrm{~N}_{2}$; f) 31c-31g: $\mathrm{NaH}$, dry DMF, $0{ }^{\circ} \mathrm{C}$-room temperature, $5 \mathrm{~h}$.

The synthesis of target compounds $\mathbf{3 6 a}-\mathbf{c}$ is listed in Scheme 4. Compound 33 was obtained by the reaction of 6 and commercially available 5-bromo-3-fluoropyridin-2(1H)-one 32 . Then, the reaction with aryl boric acids $\mathbf{3 4} \mathbf{a}-\mathbf{c}$ afforded the key intermediates, $\mathbf{3 5 a}-\mathbf{c}$, which reacted with $\mathbf{1 0}$ in the presence of $\mathrm{NaOH}$ to provide target compounds $36 \mathbf{a}-\mathbf{c}$.<smiles>CC(C)C(=O)NC=C(Br)C=C(F)C(C)C</smiles><smiles>[R]c1cc(F)c(=O)n(Cc2cccc(-c3ncc(F)cn3)c2)c1</smiles>

32<smiles>O=c1c(F)cc(Br)cn1Cc1cccc(-c2ncc(F)cn2)c1</smiles><smiles>CN(C)CCCSc1cnc(-c2cccc(Cn3cc(I)cc(F)c3=O)c2)nc1</smiles>

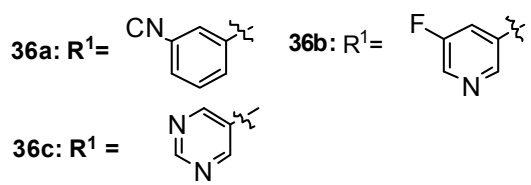

Scheme 4. Reagents and conditions: a) $\mathrm{K}_{2} \mathrm{CO}_{3}$, dry DMF, $80{ }^{\circ} \mathrm{C}, 12 \mathrm{~h}$; b) $\mathrm{PdCl}_{2}\left(\mathrm{PPh}_{3}\right)_{2}, \mathrm{Na}_{2} \mathrm{CO}_{3}$, $\mathrm{DME} / \mathrm{DMF} /$ water, $89^{\circ} \mathrm{C}, 12 \mathrm{~h}$; c) $\mathrm{NaOH}, \mathrm{DMF} / \mathrm{H}_{2} \mathrm{O}, 60^{\circ} \mathrm{C}, 8 \mathrm{~h}, \mathrm{~N}_{2}$. 
The synthesis of target compound $\mathbf{3 9}$ is outlined in Scheme 5. Intermediate $\mathbf{2 9}$ reacted with 32 to produce compound 37. Compound 38 was prepared by the Suzuki coupling reaction of 37 and (3-cyanophenyl)boronic acid. Finally, the reaction of compound 38 with 10 afforded target compound 39.<smiles>Cc1cnc(-c2cccc(C(C)Cl)c2)nc1</smiles>

29<smiles>O=c1[nH]cc(Br)cc1F</smiles>

32<smiles>CC(c1cccc(-c2ncc(F)cn2)c1)n1cc(Br)cc(F)c1=O</smiles><smiles>CC(c1cccc(-c2ncc(F)cn2)c1)n1cc(-c2cccc([N+]#N)c2)cc(F)c1=O</smiles>

38

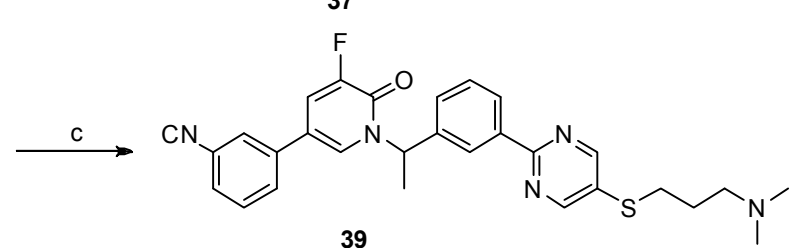

Scheme 5. Reagents and conditions: a) $\mathrm{K}_{2} \mathrm{CO}_{3}$, dry DMF, $80{ }^{\circ} \mathrm{C}, 12 \mathrm{~h}$; b) $\mathrm{PdCl}_{2}\left(\mathrm{PPh}_{3}\right)_{2}, \mathrm{Na}_{2} \mathrm{CO}_{3}$, $\mathrm{DME} / \mathrm{DMF} /$ water, $\left.89^{\circ} \mathrm{C}, 12 \mathrm{~h} ; \mathrm{c}\right) \mathrm{NaOH}, \mathrm{DMF} / \mathrm{H}_{2} \mathrm{O}, 60^{\circ} \mathrm{C}, 8 \mathrm{~h}, \mathrm{~N}_{2}$.

\subsection{Biological Evaluation}

\subsubsection{In Vitro Growth Inhibition of Human Cancer Cell Lines.}

Hepatocellular carcinoma (HCC), a primary liver cancer with a high mortality rate, accounts for $90 \%$ of all liver cancers. It is the most common malignant tumor worldwide, especially in Asia, Africa, and southern Europe. China is the "hardest hit" by liver cancer, and the number of annual deaths from this condition in China accounts for about $50 \%$ of the total number of liver cancer deaths worldwide. C-Met overexpression, mutational activation, and amplification have been found in some types of cancer, including liver cancer $[4,5]$. Therefore, hepatic carcinoma $97 \mathrm{H}$ cells were selected for the evaluation of the anti-tumor activity of the synthesized compounds, and the results are summarized in Table 1. Most compounds displayed good antiproliferative activity. Among them, compound 31e, 5-(3-cyanophenyl)-1-(1-(3-(5-((1-methylpiperidin-4-yl)methoxy)pyrimidin-2-yl)phenyl)ethyl)pyrimidin $-2(1 \mathrm{H})$-one, exhibited the best result with $26 \mathrm{nM}$ of the $\mathrm{IC}_{50}$ value. Further study of the structure-activity relationship indicated the pyridazinone ring or pyrimidin-2(1H)-one ring plays an important role in antiproliferative activity. Compounds $\mathbf{1 1 a}$ and $\mathbf{1 1} \mathbf{b}$, pyrazin-2(1H)-one derivatives, that were obtained by shifting the nitrogen from the $\mathrm{C}-1$ to $\mathrm{C}-5$ position of pyridazin-3(2H)-one, displayed poor activity ( $\mathrm{IC}_{50}$ values: $9.8 \mu \mathrm{M}$ for $11 \mathrm{a}$ and $9.1 \mu \mathrm{M}$ for $\mathbf{1 1 b}$ ). Interestingly, compounds 18 and 25, which were obtained by shifting the nitrogen from the $\mathrm{C}-1$ to the $\mathrm{C}-4$ position, resulted in significant improvement in anti-proliferative potency $\left(\mathrm{IC}_{50}: 0.36-0.55 \mu \mathrm{M}\right)$. Compounds 31a-g, which have a methyl substitution on the methylene carbon between pyrimidin-2(1H)-one and the benzene ring, provided $0.3606 \mu \mathrm{M}$ to $0.026 \mu \mathrm{M}$ of the $\mathrm{IC}_{50}$ value. This indicates that the methyl substitution at this position is favorable for antiproliferative activity. Compounds Rac-31e and $(R)-31 e$ with cyclic piperidinylmethyloxy substitution showed excellent activity $\left(\mathrm{IC}_{50}=0.026 \mu \mathrm{M}, 0.018 \mu \mathrm{M}\right)$. However, the $(S)$-31e almost lost activity $\left(\mathrm{IC}_{50}=1.834 \mu \mathrm{M}\right)$. The replacement of the pyridazinone moiety with 3-fluoropyridin-2(1H)-one moiety afforded compounds 36a-c. Compound 36a showed the best result of the 3-fluoropyridin-2(1H)-one derivatives, indicating that the benzonitrile group is more favorable than the other two substitutions. 
Table 1. Structures and antiproliferative activity of target compounds.

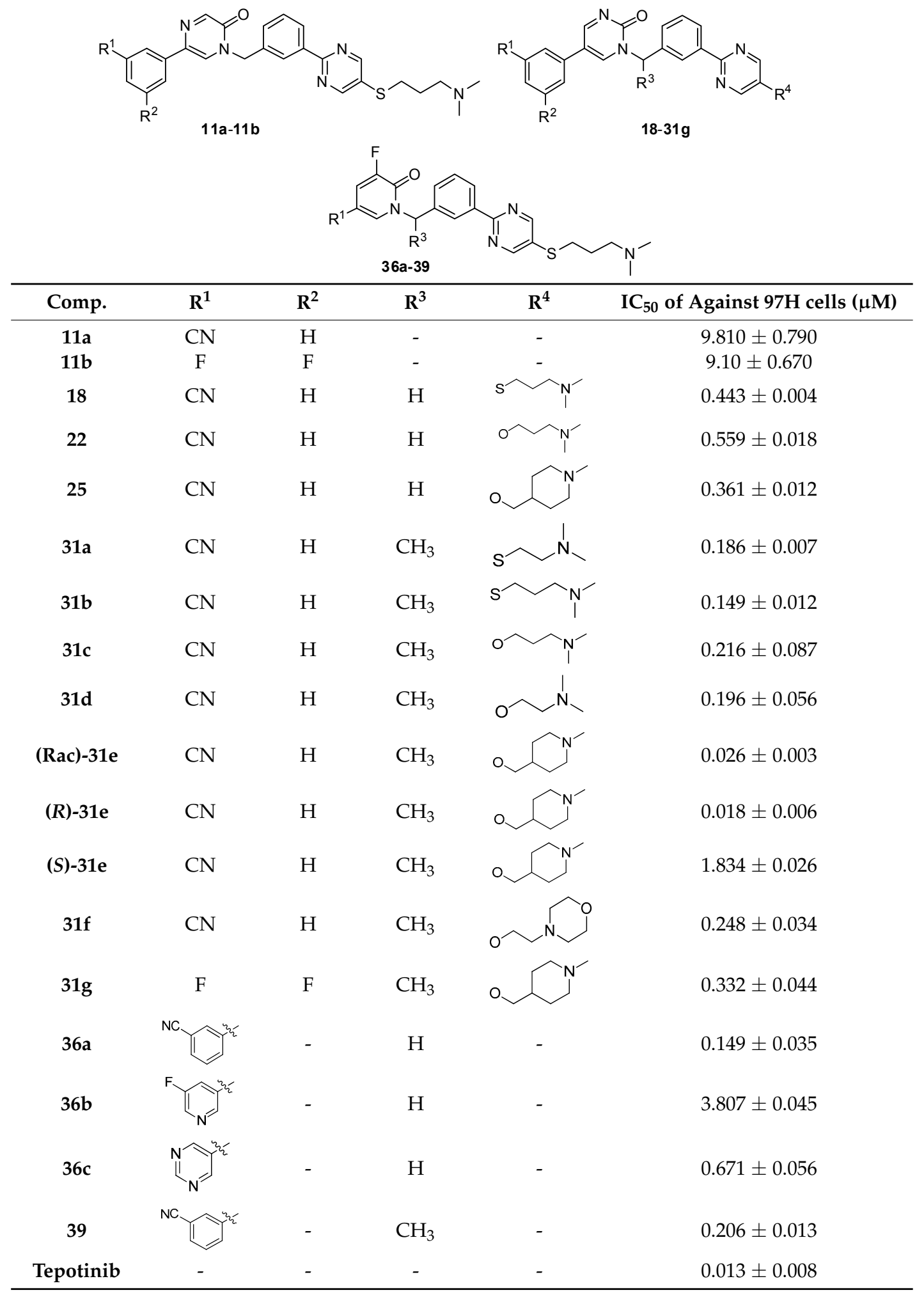

\subsubsection{Effect of Compound 31e on Cell Cycle Progression}

To evaluate the ability of compound 31e to disrupt the regulated cell cycle distribution, we performed flow cytometry analysis to determine the arrest effect of 31e on the G1 transition, a rigorously regulated process in the cell cycle. The results in Figure 3 show that 31e can arrest cells in the G1 phase in a dose-dependent manner. When hepatic carcinoma $97 \mathrm{H}$ cells were treated with $10 \mathrm{nM}$ of $31 \mathrm{e}$ 
for $24 \mathrm{~h}$, the population of cells in the G1 phase (83.84\%) increased compared to that of the vehicle (DMSO, 70.42\%), along with concomitant losses in the G2/M phase. This phenomenon was more obvious at a concentration of $100 \mathrm{nM}$. A population of up to $90.88 \%$ cells was found in the G1 phase. Correspondingly, a population of only $5.78 \%$ cells was found in the G2/M phase.

A

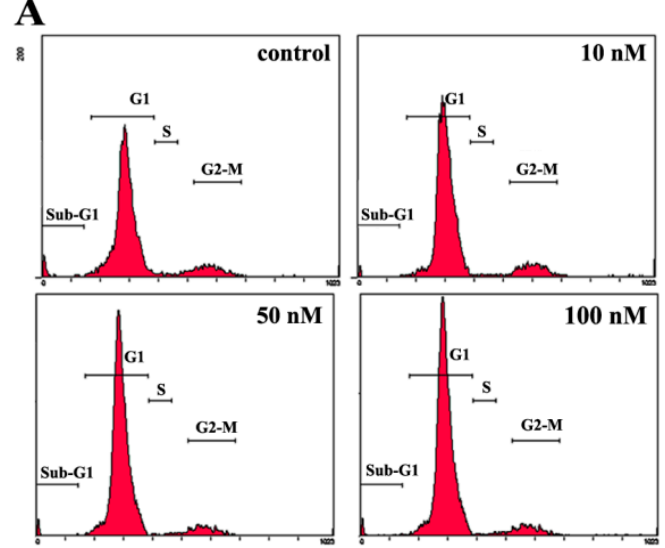

B

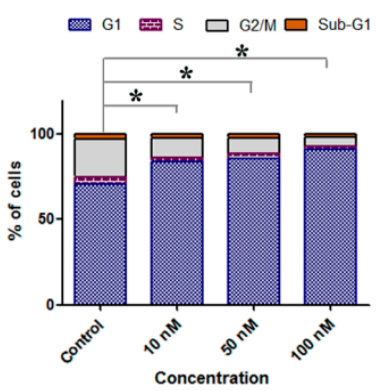

Figure 3. Effect of 31e on cell cycle progression. (A) $97 \mathrm{H}$ cells $\left(3 \times 10^{5}\right.$ cells $/$ sample) were treated with increasing concentrations of 31e for $24 \mathrm{~h}$, cells were harvested, fixed with $70 \%$ ethanol, and stained with propidium iodide (PI). The cellular DNA content was then determined by flow cytometry analysis. (B) Quantitative analysis of the percentage of cells in each cell cycle phase was analyzed by EXPO32 $\mathrm{ADC}$ analysis software. The data were presented as the mean $\pm \mathrm{SEM}{ }^{*} \mathrm{P}<0.05$, significantly different compared with the control by $t$ test.

\subsubsection{Inhibition of the Migration of Hepatic Carcinoma 97H Cells with Compound 31e}

Tumor cell migration is one of the major causes of death in cancer patients. To evaluate the inhibitory ability of 31e against tumor cell migration, hepatic carcinoma $97 \mathrm{H}$ cells $\left(5 \times 10^{4}\right.$ cells per well) were seeded in six-well plates with or without the presence of 31e and cultured as confluent monolayers. The results shown in Figure 4 demonstrate that 31e can inhibit tumor cells' migration. At a concentration of $10 \mathrm{nM}, 31 \mathrm{e}$ displayed moderate inhibition of migration. Migration was significantly suppressed when 31e was used at a dosage of $50 \mathrm{nM}$. Tumor cells' migration was completely suppressed with $100 \mathrm{nM}$ of 31e.
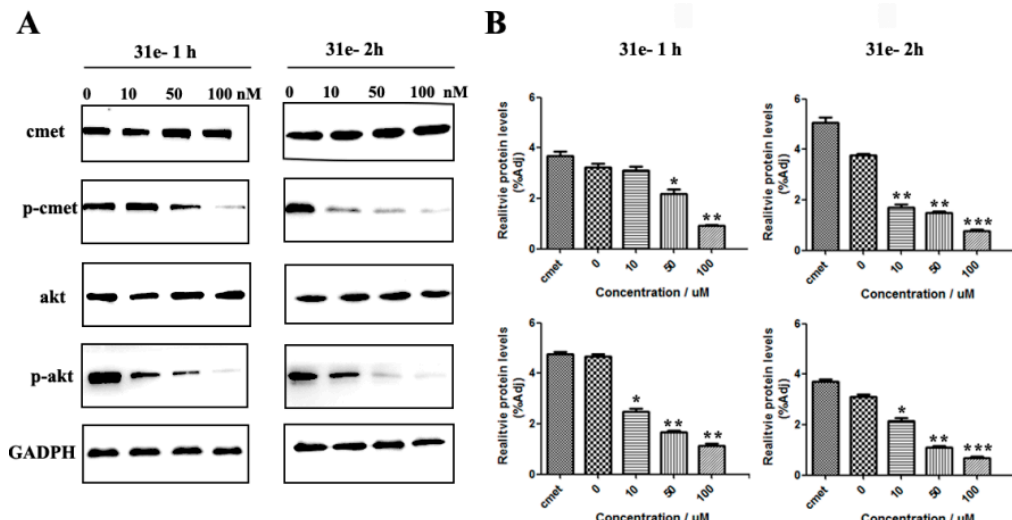

Figure 4. Effect of 31e on the migration of hepatic carcinoma 97H cells. Hepatic carcinoma 97H cells $\left(50 \times 10^{4}\right.$ cells) suspended in free serum Dulbecco's Modified Eagle Medium (DMEM) containing 31e for $36 \mathrm{~h}$ were photographed under a phase contrast microscopy (magnification: $4 \times$ objective). All results were expressed as the mean $\pm \mathrm{SD}$ of at least three independent experiments. 
2.2.4. Inhibition of Phosphorylation of c-Met and its Downstream Signaling Component, Akt, with Compound 31e

To further study the antiproliferative mechanism of compound 31e, we analyzed its effects on the phosphorylation of c-Met and its downstream signaling component, Akt, in hepatic carcinoma 97H cells, which overexpress c-Met. As shown in Figure 5A, when hepatic carcinoma 97H cells were treated with compound 31e at a concentration of 10 or $50 \mathrm{nM}$ for $1 \mathrm{~h}$, the phosphorylation level of Akt and c-Met was suppressed in a dose-dependent manner. When $100 \mathrm{nM}$ of compound 31e was used, the phosphorylation of both c-Met and Akt was completely inhibited. When $97 \mathrm{H}$ cells were treated at the same concentration of compound 31e for $2 \mathrm{~h}$, the inhibition of c-Met and Akt phosphorylation was more obvious (Figure 5B).

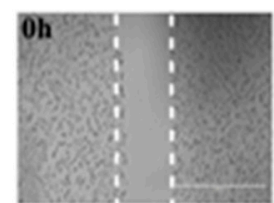

DMSO $(0.1 \%)$

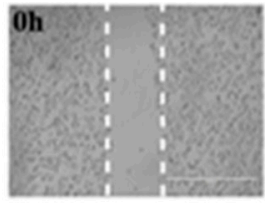

$31 \mathrm{e}-50 \mathrm{nM}$

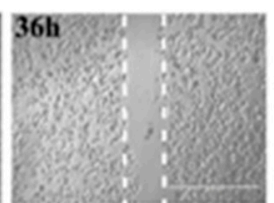

DMSO $(0.1 \%)$

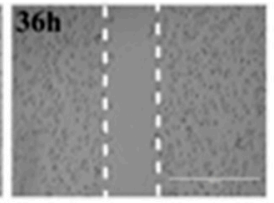

$31 \mathrm{e}-50 \mathrm{nM}$

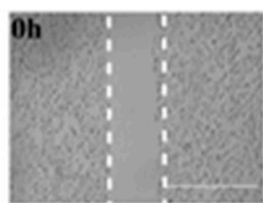

$31 \mathrm{e}-10 \mathrm{nM}$

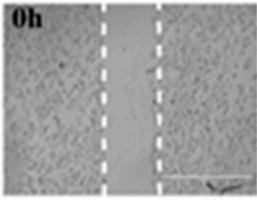

$31 \mathrm{e}-100 \mathrm{nM}$

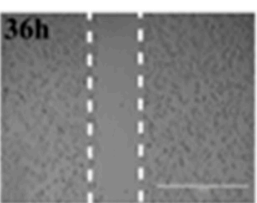

31e-10 nM

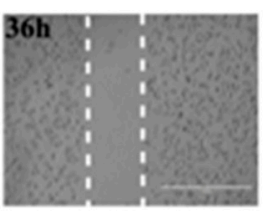

$31 \mathrm{e}-100 \mathrm{nM}$

Figure 5. Compound 31e inhibits c-Met phosphorylation and downstream signaling in cancer cell lines. Cells treated with compound 31e for $1 \mathrm{~h}$ or $2 \mathrm{~h}$ were then lysed and subjected to Western blot analysis.

\subsubsection{Selectivity of 31e towards Other Cancer Cells and Normal Human Cells}

To evaluate the selectivity of 31e towards other cancer cells and normal human cells, the antiproliferative activities against Pc9 (human non-small cell lung cancer cells), Hela (human epithelial cervical cancer cells), SJSA1 (human osteosarcoma cells), LO2 (human normal cells), and HLF (human embryonic lung fibroblast cells) were examined. As shown in Table 2, compound 31e barely inhibited the cancer cells (Pc9, Hela, SJSA1) and normal cells (LO2, HLF), demonstrating that it exclusively inhibits $97 \mathrm{H}$ cancer cells. The reason for this remains to be further investigated.

Table 2. The inhibitory activity of compound 31e against cancer cells (97H, Pc9, Hela, SJSA1), human normal cells (LO2 and HLF), and c-Met enzyme.

\begin{tabular}{ccccccc}
\hline \multicolumn{7}{c}{ IC $_{\mathbf{5 0}}(\boldsymbol{\mu M})$} \\
\hline Comp. & Pc9 & Hela & SJSA1 & LO2 & HLF & C-Met \\
\hline 31e & $42.9 \pm 0.13$ & $>50$ & $>50$ & $>50$ & $>50$ & $0.032 \pm 0.06$ \\
Tepotinib & $8.105 \pm 0.012$ & $11.22 \pm 0.32$ & $12.17 \pm 0.35$ & $10.33 \pm 0.46$ & $9.44 \pm 0.15$ & $0.004 \pm 0.001$ \\
\hline
\end{tabular}

\section{Experimental Section}

\subsection{Chemistry}

${ }^{1} \mathrm{H}-\mathrm{NMR}$ and ${ }^{13} \mathrm{C}-\mathrm{NMR}$ spectra were recorded on a Bruker AVANCE 400 or 500 spectrometer (Karlsruhe, Germany). Chemical shifts of protons are reported in parts per million downfield from tetramethylsilane. Peaks are labeled as single (s), broad singlet (br), doublet (d), triplet (t), double doublet $(\mathrm{dd})$, doublet of triplets $(\mathrm{dt})$, or multiplet $(\mathrm{m})$. The high-resolution mass spectra were analyzed on a SHIMADZU LCMS-IT-TOF mass spectrometer. The purity of the synthesized compounds was determined by high-performance liquid chromatography (HPLC) (Agilent, Palo Alto, CA, USA) with 
a TC-C18 column $(250 \mathrm{~mm} \times 4.6 \mathrm{~mm}, 5 \mu \mathrm{m})$ using methanol (1/1000 diethylamine)/water mobile phase $(0.50 \mathrm{~mL} / \mathrm{min})$. Melting points were determined in open capillary tubes on a MPA100 Optimelt automated melting point system (Stanford Research Systems, San Francisco, CA, USA,). All chemicals were purchased from Sigma-Aldrich and Alfa Aesar chemical companies (Shanghai, China) and were used without further purification.

Synthesis of 5-(3-cyanophenyl)-1-(3-(5-((3-(dimethylamino)propyl)thio)pyrimidin-2-yl)benzyl) pyrazin-2(1H)-one (11a). In a $200 \mathrm{~mL}$ two-necked round-bottomed flask provided with a magnetic stirrer and condenser, $50 \mathrm{mmol}$ of thiourea 9 were dissolved in $60 \mathrm{~mL}$ of absolute ethanol. Compound $8(3.161 \mathrm{mg}, 20 \mathrm{mmol})$ was added in one portion in the thiourea solution. After heating at reflux for $12 \mathrm{~h}$, the reaction mixture was concentrated by rotary evaporation under reduced pressure. The desired compound $\mathbf{1 0}$ was obtained as a white solid and was further used without purification [18].

$\mathrm{NaOH}(135 \mathrm{mg}, 3.375 \mathrm{mmol})$ in $0.5 \mathrm{~mL}$ water was added to a mixture of $7 \mathbf{a}(287.25 \mathrm{mg}$, $0.75 \mathrm{mmol})$ and $10(444 \mathrm{mg})$ in DMF $(5 \mathrm{~mL})$ under nitrogen, and the mixture was stirred at room temperature for $15 \mathrm{~min}$. Then, the mixture was stirred at $60{ }^{\circ} \mathrm{C}$ under nitrogen for $8 \mathrm{~h}$. The reaction mixture was allowed to cool to room temperature. The aqueous phase was extracted with dichloromethane $(30 \mathrm{~mL} \times 3)$. The combined organic layer was washed with $\mathrm{H}_{2} \mathrm{O}(15 \mathrm{~mL})$ and brine $(10 \mathrm{~mL})$, and then dried over anhydrous $\mathrm{Na}_{2} \mathrm{SO}_{4}$, filtered, and evaporated in vacuo. The residue was purified by flash chromatography over silica gel ( $\mathrm{DCM} / \mathrm{MeOH}=40: 1-10: 1)$ to give 5-(3-cyanophenyl)-1-(3-(5-((3-(dimethylamino)propyl)thio)pyrimidin-2-yl)benzyl)pyrazin-2(1H)-one (11a) $(224 \mathrm{mg}, 62 \%)$ as a white solid. m.p. $106.3-107.9^{\circ} \mathrm{C} .{ }^{1} \mathrm{H}-\mathrm{NMR}\left(400 \mathrm{MHz}, \mathrm{CDCl}_{3}\right) \delta 8.74(\mathrm{~s}, 1 \mathrm{H})$, $8.46-8.39(\mathrm{~m}, 2 \mathrm{H}), 8.32(\mathrm{~s}, 1 \mathrm{H}), 8.01(\mathrm{~s}, 1 \mathrm{H}), 7.93(\mathrm{~d}, J=8.0 \mathrm{~Hz}, 1 \mathrm{H}), 7.64(\mathrm{~s}, 1 \mathrm{H}), 7.58(\mathrm{~d}, J=7.7 \mathrm{~Hz}, 1 \mathrm{H})$, 7.55-7.47 (m, 3H), $5.27(\mathrm{~s}, 2 \mathrm{H}), 3.03(\mathrm{t}, J=7.2 \mathrm{~Hz}, 2 \mathrm{H}), 2.43(\mathrm{t}, J=7.0 \mathrm{~Hz}, 2 \mathrm{H}), 2.24(\mathrm{~s}, 6 \mathrm{H}), 1.91-1.76$ $(\mathrm{m}, 2 \mathrm{H}) ;{ }^{13} \mathrm{C}-\mathrm{NMR}\left(101 \mathrm{MHz}, \mathrm{CDCl}_{3}\right) \delta 161.18,157.41,155.35,149.17,138.08,136.67,134.95,131.70$, 131.28, 130.82, 129.79, 129.70, 129.08, 128.52, 128.04, 125.10, 118.62, 113.06, 57.87, 52.29, 45.34, 31.60, 27.04. HRMS (ESI) calculated for $\mathrm{C}_{27} \mathrm{H}_{26} \mathrm{~N}_{6} \mathrm{OS}[\mathrm{M}+\mathrm{H}]^{+}: 483.1962$, found: 483.1947 . Purity: $98.3 \%$ (by HPLC).

5-(3,5-difluorophenyl)-1-(3-(5-((3-(dimethylamino)propyl)thio)pyrimidin-2-yl)benzyl)pyrazin-2(1H) -one (11b). Compound $\mathbf{1 1 b}$ was prepared via a similar procedure of 11a. White solid. m.p. 143.7-145.2 ${ }^{\circ} \mathrm{C}$. Yield: $65 \% .{ }^{1} \mathrm{H}-\mathrm{NMR}\left(500 \mathrm{MHz}, \mathrm{CDCl}_{3}\right) \delta 8.74(\mathrm{~s}, 2 \mathrm{H}), 8.46-8.39(\mathrm{~m}, 2 \mathrm{H}), 8.30(\mathrm{~s}, 1 \mathrm{H})$, $7.56(\mathrm{~s}, 1 \mathrm{H}), 7.54-7.46(\mathrm{~m}, 2 \mathrm{H}), 7.25-7.18(\mathrm{~m}, 2 \mathrm{H}), 6.82-6.65(\mathrm{~m}, 1 \mathrm{H}), 5.25(\mathrm{~s}, 2 \mathrm{H}), 3.03(\mathrm{t}, J=7.2 \mathrm{~Hz}, 2 \mathrm{H})$, $2.42(\mathrm{t}, J=7.0 \mathrm{~Hz}, 2 \mathrm{H}), 2.24(\mathrm{~s}, 6 \mathrm{H}), 1.92-1.76(\mathrm{~m}, 2 \mathrm{H}) .{ }^{13} \mathrm{C}-\mathrm{NMR}\left(126 \mathrm{MHz}, \mathrm{CDCl}_{3}\right) \delta 164.52\left(J_{\mathrm{CF}}=\right.$ $247.5 \mathrm{~Hz}), 163.42\left(J_{C F}=246.25 \mathrm{~Hz}\right), 161.21,157.45,155.37,148.97,138.74\left(J_{C F}=10.0 \mathrm{~Hz}\right), 138.10,134.92$, $131.64\left(J_{\mathrm{CF}}=3.0 \mathrm{~Hz}\right), 130.81,130.76,129.76,128.49,128.00,125.03,107.79\left(J_{C F}=26.25 \mathrm{~Hz}\right), 107.78$ $\left(J_{C F}=13.75 \mathrm{~Hz}\right), 103.21\left(J_{C F}=26.25 \mathrm{~Hz}\right), 57.89,52.24,45.38,31.65,27.11$. HRMS (ESI) calculated for $\mathrm{C}_{26} \mathrm{H}_{25} \mathrm{~N}_{5} \mathrm{OF}_{2} \mathrm{~S}[\mathrm{M}+\mathrm{H}]^{+}:$494.1821, found: 494.1823. Purity: 99.7\% (by HPLC).

5-(3-cyanophenyl)-1-(3-(5-((3-(dimethylamino)propyl)thio)pyrimidin-2-yl)benzyl)pyrimidin-2(1H) -one (18). Compound 18 was prepared via a similar procedure of 11a. White oil. Yield: $77.1 \%$. ${ }^{1} \mathrm{H}-\mathrm{NMR}\left(500 \mathrm{MHz}, \mathrm{CDCl}_{3}\right) \delta 8.82(\mathrm{~d}, J=3.2 \mathrm{~Hz}, 1 \mathrm{H}), 8.69(\mathrm{~s}, 2 \mathrm{H}), 8.42(\mathrm{~s}, 1 \mathrm{H}), 8.38(\mathrm{~d}, J=7.6 \mathrm{~Hz}, 1 \mathrm{H})$, $7.99(\mathrm{~d}, J=3.2 \mathrm{~Hz}, 1 \mathrm{H}), 7.65(\mathrm{~s}, 1 \mathrm{H}), 7.60(\mathrm{t}, J=7.1 \mathrm{~Hz}, 2 \mathrm{H}), 7.55-7.46(\mathrm{~m}, 3 \mathrm{H}), 5.28(\mathrm{~s}, 2 \mathrm{H}), 3.01(\mathrm{t}$, $J=7.2 \mathrm{~Hz}, 2 \mathrm{H}), 2.40(\mathrm{t}, J=7.0 \mathrm{~Hz}, 2 \mathrm{H}), 2.21(\mathrm{~s}, 6 \mathrm{H}), 1.86-1.76(\mathrm{~m}, 2 \mathrm{H}) .{ }^{13} \mathrm{C}-\mathrm{NMR}\left(126 \mathrm{MHz}, \mathrm{CDCl}_{3}\right)$ $\delta 164.70,161.23,157.43,155.73,145.11,138.15,135.10,134.64,131.48,131.11,130.93,130.32,130.14$, $129.83,129.37,128.58,128.18,118.25,116.63,57.95,54.44,45.43,31.67,27.17$. HRMS (ESI) calculated for $\mathrm{C}_{27} \mathrm{H}_{26} \mathrm{~N}_{6} \mathrm{OS}[\mathrm{M}+\mathrm{H}]^{+}:$483.1962, found: 483.1942. Purity: 98.3\% (by HPLC).

Synthesis of 5-(3-cyanophenyl)-1-(3-(5-(3-(dimethylamino)propoxy)pyrimidin-2-yl)benzyl)pyrimidin -2(1H)-one (22). Compound 21a (157.85 mg, $0.55 \mathrm{mmol}$ ) and triphenylphosphine (328 mg, $1.25 \mathrm{mmol})$ were added successively to a suspension of $\mathbf{1 6}(116.75 \mathrm{mg}, 0.5 \mathrm{mmol})$ in THF $(5 \mathrm{~mL})$ under nitrogen. A solution of diisopropyl azodicarboxylate $(104.49 \mathrm{mg}, 0.6 \mathrm{mmol})$ in THF $(1 \mathrm{~mL})$ was then slowly added dropwise with ice cooling. The resultant solution was stirred at room temperature for $12 \mathrm{~h}$. The 
aqueous phase was extracted with dichloromethane $(30 \mathrm{~mL} \times 3)$. The combined organic layer was washed with $\mathrm{H}_{2} \mathrm{O}(20 \mathrm{~mL})$ and brine $(10 \mathrm{~mL})$, and then dried over anhydrous $\mathrm{Na}_{2} \mathrm{SO}_{4}$, filtered, and evaporated in vacuo. The residue was purified by flash chromatography over silica gel (DCM/MeOH $=40: 1-10: 1)$ to give 22 [14]. Yellow solid. m.p. $122.3-123.6{ }^{\circ} \mathrm{C}$. Yield: $45 \% .{ }^{1} \mathrm{H}-\mathrm{NMR}\left(500 \mathrm{MHz}, \mathrm{CDCl}_{3}\right)$ $\delta 8.84(\mathrm{~d}, J=3.0 \mathrm{~Hz}, 1 \mathrm{H}), 8.45(\mathrm{~s}, 2 \mathrm{H}), 8.40-8.33(\mathrm{~m}, 2 \mathrm{H}), 7.91(\mathrm{~d}, J=3.0 \mathrm{~Hz}, 1 \mathrm{H}), 7.66-7.57(\mathrm{~m}, 3 \mathrm{H})$, 7.56-7.47 (m, 3H), $5.29(\mathrm{~s}, 2 \mathrm{H}), 4.18(\mathrm{t}, J=6.2 \mathrm{~Hz}, 2 \mathrm{H}), 2.53(\mathrm{t}, J=6.2 \mathrm{~Hz}, 2 \mathrm{H}), 2.31(\mathrm{~s}, 6 \mathrm{H}), 2.07-2.00(\mathrm{~m}$, 2H). ${ }^{13} \mathrm{C}-\mathrm{NMR}\left(126 \mathrm{MHz}, \mathrm{CDCl}_{3}\right) \delta 164.56,156.67,155.65,151.81,144.80,143.87,138.53,134.73,134.60$, 131.43, 130.25, 130.20, 130.09, 129.76, 129.26, 128.14, 127.78, 118.14, 116.54, 113.67, 67.04, 55.84, 54.31, 45.37, 27.17. HRMS (ESI) calculated for $\mathrm{C}_{27} \mathrm{H}_{26} \mathrm{~N}_{6} \mathrm{O}_{2}[\mathrm{M}+\mathrm{H}]^{+}$: 467.2190, found: 467.2185. Purity: $96.784 \%$ (by HPLC).

Synthesis of 5-(3-cyanophenyl)-1-(3-(5-((1-methylpiperidin-4-yl)methoxy)pyrimidin-2-yl)benzyl) pyrimidin-2(1H)-one (25). 2-(3-(chloromethyl)phenyl)-5-((1-methylpiperidin-4-yl)methoxy)pyrimidine $24(99 \mathrm{mg}, 0.3 \mathrm{mmol}, 1$ eq.) and potassium carbonate $(124 \mathrm{mg}, 0.9 \mathrm{mmol}, 3$ eq.) were added to a suspension of $16(77 \mathrm{mg}, 0.33 \mathrm{mmol})$ in dry DMF $(2 \mathrm{~mL})$, and the mixture was stirred at $80^{\circ} \mathrm{C}$ for $12 \mathrm{~h}$. The reaction mixture was allowed to cool to room temperature. The aqueous phase was extracted with dichloromethane $(10 \mathrm{~mL} \times 3)$. The combined organic layer was washed with $\mathrm{H}_{2} \mathrm{O}(5 \mathrm{~mL})$ and brine $(10 \mathrm{~mL})$, and then dried over anhydrous $\mathrm{Na}_{2} \mathrm{SO}_{4}$, filtered, and evaporated in vacuo. The residue was purified by flash chromatography over silica gel $(\mathrm{DCM} / \mathrm{MeOH}=30: 1-10: 1)$ to give compound 25 [15]. White solid. m.p. $116.7-118.2{ }^{\circ} \mathrm{C}$. Yield: $48 \% .{ }^{1} \mathrm{H}-\mathrm{NMR}\left(500 \mathrm{MHz}, \mathrm{CDCl}_{3}\right) \delta 8.84(\mathrm{~d}, J=2.9 \mathrm{~Hz}, 1 \mathrm{H})$, $8.44(\mathrm{~s}, 2 \mathrm{H}), 8.39-8.33(\mathrm{~m}, 2 \mathrm{H}), 7.89(\mathrm{~d}, J=2.6 \mathrm{~Hz}, 1 \mathrm{H}), 7.65-7.60(\mathrm{~m}, 2 \mathrm{H}), 7.60-7.56(\mathrm{~m}, 1 \mathrm{H}), 7.56-7.47$ $(\mathrm{m}, 3 \mathrm{H}), 5.29(\mathrm{~s}, 2 \mathrm{H}), 3.96(\mathrm{~d}, J=5.6 \mathrm{~Hz}, 2 \mathrm{H}), 2.98(\mathrm{~d}, J=11.1 \mathrm{~Hz}, 2 \mathrm{H}), 2.34(\mathrm{~s}, 3 \mathrm{H}), 2.04(\mathrm{t}, J=11.8 \mathrm{~Hz}$, 2H), 1.89-1.81 (m, 3H), 1.54-1.46 (m, 2H). ${ }^{13} \mathrm{C}-\mathrm{NMR}\left(126 \mathrm{MHz}, \mathrm{CDCl}_{3}\right) \delta 164.56,156.70,155.63,151.85$, $144.72,143.82,138.52,134.73,134.61,131.43,130.25,130.22,130.08,129.77,129.26,128.15,127.77,118.13$, $116.53,113.68,73.28,55.16,54.30,46.21,35.17,28.69$. HRMS (ESI) calculated for $\mathrm{C}_{29} \mathrm{H}_{28} \mathrm{~N}_{6} \mathrm{O}_{2}[\mathrm{M}+\mathrm{H}]^{+}$: 493.2347, found: 493.2351 . Purity: $97.8 \%$ (by HPLC).

5-(3-cyanophenyl)-1-(1-(3-(5-((2-(dimethylamino)ethyl)thio)pyrimidin-2-yl)phenyl)ethyl)pyrimidin -2(1H)-one (31a). Compound 31a was prepared via a similar procedure of 11a. Yellow oil. Yield: $66 \%$. ${ }^{1} \mathrm{H}$ NMR $\left(400 \mathrm{MHz}, \mathrm{CDCl}_{3}\right) \delta 8.78(\mathrm{~d}, J=3.3 \mathrm{~Hz}, 1 \mathrm{H}), 8.74(\mathrm{~s}, 2 \mathrm{H}), 8.48(\mathrm{~s}, 1 \mathrm{H}), 8.42(\mathrm{~d}, J=7.5 \mathrm{~Hz}, 1 \mathrm{H})$, $7.71(\mathrm{~d}, J=3.3 \mathrm{~Hz}, 1 \mathrm{H}), 7.63-7.53(\mathrm{~m}, 3 \mathrm{H}), 7.52-7.45(\mathrm{~m}, 3 \mathrm{H}), 6.35(\mathrm{q}, J=6.9 \mathrm{~Hz}, 1 \mathrm{H}), 3.08(\mathrm{t}, J=7.1 \mathrm{~Hz}$, $2 \mathrm{H}), 2.60(\mathrm{t}, J=7.1 \mathrm{~Hz}, 2 \mathrm{H}), 2.28(\mathrm{~s}, 6 \mathrm{H}), 1.90(\mathrm{~d}, J=7.0 \mathrm{~Hz}, 3 \mathrm{H}) .{ }^{13} \mathrm{C}-\mathrm{NMR}\left(126 \mathrm{MHz}, \mathrm{CDCl}_{3}\right) \delta 164.01$, 161.33, 157.54, 155.44, 142.40, 138.86, 138.26, 134.89, 131.45, 130.97, 130.31, 130.15, 129.84, 129.32, 128.64, $126.92,118.22,116.76,113.72,58.36,56.32,45.37,32.02,19.19$. HRMS (ESI) calculated for $\mathrm{C}_{27} \mathrm{H}_{26} \mathrm{~N}_{6} \mathrm{OS}$ $[\mathrm{M}+\mathrm{H}]^{+}:$483.1962, found: 483.1949. Purity: 98\% (by HPLC).

5-(3-cyanophenyl)-1-(1-(3-(5-((3-(dimethylamino)propyl)thio)pyrimidin-2-yl)phenyl)ethyl)pyrimidin $\mathbf{- 2}(\mathbf{1 H})$-one $\mathbf{( 3 1 b )}$. Compound $\mathbf{3 1 b}$ was prepared via a similar procedure of $\mathbf{1 1 a}$. Yellow oil. Yield: $75 \%$. ${ }^{1} \mathrm{H}$ NMR $\left(500 \mathrm{MHz}, \mathrm{CDCl}_{3}\right) \delta 8.78(\mathrm{~d}, J=3.2 \mathrm{~Hz}, 1 \mathrm{H}), 8.73(\mathrm{~s}, 2 \mathrm{H}), 8.49(\mathrm{~s}, 1 \mathrm{H}), 8.42(\mathrm{~d}, J=7.6 \mathrm{~Hz}, 1 \mathrm{H})$, $7.70(\mathrm{~d}, J=3.2 \mathrm{~Hz}, 1 \mathrm{H}), 7.63-7.58(\mathrm{~m}, 1 \mathrm{H}), 7.57-7.46(\mathrm{~m}, 5 \mathrm{H}), 6.36(\mathrm{q}, J=6.9 \mathrm{~Hz}, 1 \mathrm{H}), 3.03(\mathrm{t}, J=7.2 \mathrm{~Hz}$, $2 \mathrm{H}), 2.42(\mathrm{t}, J=7.0 \mathrm{~Hz}, 3 \mathrm{H}), 2.23(\mathrm{~s}, 6 \mathrm{H}), 1.91(\mathrm{~d}, J=7.0 \mathrm{~Hz}, 3 \mathrm{H}), 1.88-1.77(\mathrm{~m}, 2 \mathrm{H}) .{ }^{13} \mathrm{C}-\mathrm{NMR}(126$ $\left.\mathrm{MHz}, \mathrm{CDCl}_{3}\right) \delta 164.04,161.27,157.50,155.49,142.43,138.82,138.32,134.88,131.49,131.02,130.33$, 130.31, 130.18, 129.86, 129.34, 128.66, 126.92, 118.24, 116.83, 113.74, 57.97, 56.37, 45.46, 31.70, 27.18, 19.21. HRMS (ESI) calculated for $\mathrm{C}_{28} \mathrm{H}_{28} \mathrm{~N}_{6} \mathrm{OS}[\mathrm{M}+\mathrm{H}]^{+}$: 497.2118, found: 497.2108. Purity: $97.1 \%$ (by HPLC).

Synthesis of 5-(3-cyanophenyl)-1-(1-(3-(5-(3-(dimethylamino)propoxy)pyrimidin-2-yl)phenyl)ethyl) pyrimidin-2(1H)-one (31c). A solution of 3-(dimethylamino)propan-1-ol (113.3 mg, $1.1 \mathrm{mmol}, 2 \mathrm{eq}$.) in dry $\operatorname{DMF}(5 \mathrm{~mL})$ was added to a suspension of $\mathrm{NaH}\left(43.56 \mathrm{mg}, 3.3 \mathrm{eq}\right.$.) in dry DMF $(5 \mathrm{~mL})$ at $0{ }^{\circ} \mathrm{C}$. After 30 mins, 5-(3-cyanophenyl)-1-(1-(3-(5-fluoropyrimidin-2-yl)phenyl)ethyl)pyrimidin-2(1H)-one 30a $(210 \mathrm{mg}, 0.55 \mathrm{mmol}, 1$ eq.) was added. After the reaction mixture was stirred for $5 \mathrm{~h}$, the reaction was quenched with water $(15 \mathrm{~mL})$ and the mixture was extracted with dichloromethane $(20 \mathrm{~mL} \times$ 
3). The combined organic layer was dried over anhydrous $\mathrm{Na}_{2} \mathrm{SO}_{4}$ and filtered. After the solvent was removed in vacuo, the crude product was purified by column chromatography $(\mathrm{DCM} / \mathrm{MeOH}=$ 50:1-10:1) to afford 31c as a white solid [19]. m.p. $68.3-69.9^{\circ} \mathrm{C}$. Yield: $62 \% .{ }^{1} \mathrm{H}-\mathrm{NMR}\left(400 \mathrm{MHz}, \mathrm{CDCl}_{3}\right)$ $\delta 8.78(\mathrm{~d}, J=3.4 \mathrm{~Hz}, 1 \mathrm{H}), 8.46(\mathrm{~s}, 2 \mathrm{H}), 8.42(\mathrm{~s}, 1 \mathrm{H}), 8.35(\mathrm{~d}, J=7.7 \mathrm{~Hz}, 1 \mathrm{H}), 7.73(\mathrm{~d}, J=3.4 \mathrm{~Hz}, 1 \mathrm{H})$, $7.64-7.58(\mathrm{~m}, 1 \mathrm{H}), 7.56-7.42(\mathrm{~m}, 5 \mathrm{H}), 6.35(\mathrm{q}, J=7.0 \mathrm{~Hz}, 1 \mathrm{H}), 4.21(\mathrm{t}, J=6.1 \mathrm{~Hz}, 2 \mathrm{H}), 2.75(\mathrm{t}, J=7.3 \mathrm{~Hz}$, 2H), $2.47(\mathrm{~s}, 6 \mathrm{H}), 2.24-2.09(\mathrm{p}, 2 \mathrm{H}), 1.90(\mathrm{~d}, J=7.0 \mathrm{~Hz}, 3 \mathrm{H}) .{ }^{13} \mathrm{C}-\mathrm{NMR}\left(101 \mathrm{MHz}, \mathrm{CDCl}_{3}\right) \delta$ 163.98, $156.99,155.48,151.75,144.00,142.53,138.71,138.62,134.92,131.44,130.32,130.19,129.77,129.44,129.35$, 128.22, 126.55, 118.28, 116.76, 113.69, 66.75, 56.44, 55.79, 44.79, 26.49, 19.24. HRMS (ESI) calculated for $\mathrm{C}_{28} \mathrm{H}_{28} \mathrm{~N}_{6} \mathrm{O}_{2}[\mathrm{M}+\mathrm{HCOO}]^{-}: 525.2256$, found: 525.2238. Purity: $98.3 \%$ (by HPLC).

5-(3-cyanophenyl)-1-(1-(3-(5-(2-(dimethylamino)ethoxy)pyrimidin-2-yl)phenyl)ethyl)pyrimidin-2 (1H)-one (31d). Compound 31d was prepared via a similar procedure of 31c. White solid. m.p. 53.3-55.0 ${ }^{\circ} \mathrm{C}$. Yield: $74 \% .{ }^{1} \mathrm{H}-\mathrm{NMR}\left(400 \mathrm{MHz}, \mathrm{CDCl}_{3}\right) \delta 8.80(\mathrm{~d}, J=3.3 \mathrm{~Hz}, 1 \mathrm{H}), 8.51(\mathrm{~s}, 2 \mathrm{H}), 8.45(\mathrm{~s}$, $1 \mathrm{H}), 8.38(\mathrm{~d}, J=7.7 \mathrm{~Hz}, 1 \mathrm{H}), 7.72(\mathrm{~d}, J=3.4 \mathrm{~Hz}, 1 \mathrm{H}), 7.64-7.58(\mathrm{~m}, 1 \mathrm{H}), 7.57-7.42(\mathrm{~m}, 5 \mathrm{H}), 6.38(\mathrm{q}$, $J=7.0 \mathrm{~Hz}, 1 \mathrm{H}), 4.24(\mathrm{t}, J=5.4 \mathrm{~Hz}, 2 \mathrm{H}), 2.83(\mathrm{t}, J=5.4 \mathrm{~Hz}, 2 \mathrm{H}), 2.40(\mathrm{~s}, 6 \mathrm{H}), 1.91(\mathrm{~d}, J=7.0 \mathrm{~Hz}, 3 \mathrm{H})$. ${ }^{13} \mathrm{C}-\mathrm{NMR}\left(101 \mathrm{MHz}, \mathrm{CDCl}_{3}\right) \delta 163.94,156.94,155.45,151.78,144.05,142.52,138.67,138.59,134.89$, 131.40, 130.27, 130.15, 129.73, 129.44, 129.32, 128.19, 126.53, 118.24, 116.72, 113.66, 66.88, 58.10, 56.40, 45.90, 19.18. HRMS (ESI) calculated for $\mathrm{C}_{27} \mathrm{H}_{26} \mathrm{~N}_{6} \mathrm{O}_{2}$ [M + HCOO] $]^{-}: 511.2099$, found: 511.2074. Purity: 98\% (by HPLC).

5-(3-cyanophenyl)-1-(1-(3-(5-((1-methylpiperidin-4-yl)methoxy)pyrimidin-2-yl)phenyl)ethyl)pyrimidin -2(1H)-one (31e). Compound 31e was prepared via a similar procedure of 31c. Yellow solid. m.p. 98.2-99.9 ${ }^{\circ} \mathrm{C}$. Yield: $76 \% .{ }^{1} \mathrm{H}-\mathrm{NMR}\left(500 \mathrm{MHz}, \mathrm{DMSO}-d_{6}\right) \delta 9.04(\mathrm{~d}, J=3.2 \mathrm{~Hz}, 1 \mathrm{H}), 8.72(\mathrm{~d}, J=3.2 \mathrm{~Hz}$, $1 \mathrm{H}), 8.64(\mathrm{~s}, 2 \mathrm{H}), 8.33(\mathrm{~s}, 1 \mathrm{H}), 8.27-8.18(\mathrm{~m}, 2 \mathrm{H}), 8.03(\mathrm{~d}, J=8.0 \mathrm{~Hz}, 1 \mathrm{H}), 7.81(\mathrm{~d}, J=7.7 \mathrm{~Hz}, 1 \mathrm{H}), 7.65(\mathrm{t}$, $J=7.8 \mathrm{~Hz}, 1 \mathrm{H}), 7.59-7.45(\mathrm{~m}, 2 \mathrm{H}), 6.02(\mathrm{q}, J=7.0 \mathrm{~Hz}, 1 \mathrm{H}), 4.04(\mathrm{~d}, J=5.8 \mathrm{~Hz}, 2 \mathrm{H}), 2.80(\mathrm{~d}, J=11.1 \mathrm{~Hz}$, $2 \mathrm{H}), 2.16(\mathrm{~s}, 3 \mathrm{H}), 1.92(\mathrm{~d}, J=7.2 \mathrm{~Hz}, 3 \mathrm{H}), 1.87(\mathrm{~d}, J=11.3 \mathrm{~Hz}, 2 \mathrm{H}), 1.78-1.67(\mathrm{~m}, 3 \mathrm{H}), 1.36-1.27(\mathrm{~m}$, 2H). ${ }^{13} \mathrm{C}-\mathrm{NMR}\left(101 \mathrm{MHz}, \mathrm{CDCl}_{3}\right) \delta 163.97,156.82,155.49,151.98,143.94,142.52,138.66,134.92,131.44$, 130.30, 130.17, 129.77, 129.44, 129.34, 128.21, 126.52, 118.26, 116.75, 113.71, 73.39, 56.42, 55.30, 46.35, 35.26, 28.81, 19.21. HRMS (ESI) calculated for $\mathrm{C}_{30} \mathrm{H}_{30} \mathrm{~N}_{6} \mathrm{O}_{2}[\mathrm{M}+\mathrm{HCOO}]^{-}:$551.2412, found: 551.2402. Purity: $98.9 \%$ (by HPLC).

5-(3-cyanophenyl)-1-(1-(3-(5-(2-morpholinoethoxy)pyrimidin-2-yl)phenyl)ethyl)pyrimidin-2(1H)one (31f). Compound 31f was prepared via a similar procedure of 31c. White solid. m.p. 82.3-83.9 ${ }^{\circ} \mathrm{C}$. Yield: $68 \% .{ }^{1} \mathrm{H}-\mathrm{NMR}\left(400 \mathrm{MHz}, \mathrm{CDCl}_{3}\right) \delta 8.78(\mathrm{~d}, J=3.4 \mathrm{~Hz}, 1 \mathrm{H}), 8.47(\mathrm{~s}, 2 \mathrm{H}), 8.43(\mathrm{~s}, 1 \mathrm{H}), 8.35(\mathrm{~d}$, $J=7.7 \mathrm{~Hz}, 1 \mathrm{H}), 7.72(\mathrm{~d}, J=3.4 \mathrm{~Hz}, 1 \mathrm{H}), 7.62-7.56(\mathrm{~m}, 1 \mathrm{H}), 7.56-7.42(\mathrm{~m}, 5 \mathrm{H}), 6.35(\mathrm{q}, J=7.0 \mathrm{~Hz}, 1 \mathrm{H})$, $4.25(\mathrm{t}, J=5.5 \mathrm{~Hz}, 2 \mathrm{H}), 3.79-3.66(\mathrm{~m}, 4 \mathrm{H}), 2.85(\mathrm{t}, J=5.5 \mathrm{~Hz}, 2 \mathrm{H}), 2.68-2.50(\mathrm{~m}, 4 \mathrm{H}), 1.89(\mathrm{~d}, J=7.0 \mathrm{~Hz}$, 3H). ${ }^{13} \mathrm{C}-\mathrm{NMR}\left(101 \mathrm{MHz}, \mathrm{CDCl}_{3}\right) \delta 163.95,157.05,155.45,151.72,144.13,142.50,138.70,138.56,134.91$, $131.42,130.28,130.15,129.75,129.46,129.33,128.21,126.56,118.25,116.72,113.68,66.87,66.77,57.53$, 56.39, 54.17, 19.21. HRMS (ESI) calculated for $\mathrm{C}_{29} \mathrm{H}_{28} \mathrm{~N}_{6} \mathrm{O}_{3}\left[\mathrm{M}+\mathrm{HCOO}^{-}: 553.2205\right.$, found: 553.2181. Purity: $99.6 \%$ (by HPLC).

5-(3,5-difluorophenyl)-1-(1-(3-(5-((1-methylpiperidin-4-yl)methoxy)pyrimidin-2-yl)phenyl)ethyl) pyrimidin-2(1H)-one (31g). Compound 31g was prepared via a similar procedure of 31c. White solid. m.p. 86.9-88.6 ${ }^{\circ} \mathrm{C}$. Yield: $55 \% .{ }^{1} \mathrm{H}-\mathrm{NMR}\left(500 \mathrm{MHz}, \mathrm{CDCl}_{3}\right) \delta 8.76(\mathrm{~d}, J=3.2 \mathrm{~Hz}, 1 \mathrm{H}), 8.43(\mathrm{~s}, 2 \mathrm{H}), 8.42$ $(\mathrm{s}, 2 \mathrm{H}), 8.35(\mathrm{~d}, J=7.7 \mathrm{~Hz}, 1 \mathrm{H}), 7.67(\mathrm{~d}, J=3.3 \mathrm{~Hz}, 1 \mathrm{H}), 7.51(\mathrm{t}, J=7.7 \mathrm{~Hz}, 1 \mathrm{H}), 7.47-7.39(\mathrm{~m}, 1 \mathrm{H})$, 6.82-6.69 (m, 3H), $6.35(\mathrm{q}, J=6.9 \mathrm{~Hz}, 1 \mathrm{H}), 3.95(\mathrm{~d}, J=5.7 \mathrm{~Hz}, 2 \mathrm{H}), 3.00(\mathrm{~d}, J=11.2 \mathrm{~Hz}, 2 \mathrm{H}), 2.35(\mathrm{~s}$, $3 \mathrm{H}), 2.08(\mathrm{t}, J=11.5 \mathrm{~Hz}, 2 \mathrm{H}), 1.93-1.77(\mathrm{~m}, 6 \mathrm{H}), 1.60-1.49(\mathrm{~m}, 2 \mathrm{H}) .{ }^{13} \mathrm{C}-\mathrm{NMR}\left(126 \mathrm{MHz}, \mathrm{CDCl}_{3}\right) \delta$ $163.92,163.665\left(J_{C F}=248.75 \mathrm{~Hz}\right), 163.565\left(J_{C F}=248.75 \mathrm{~Hz}\right), 156.88,155.54,151.94,143.92,142.42,138.69$, $138.65,136.67\left(J_{C F}=10.0 \mathrm{~Hz}\right), 129.74,129.36,128.18,126.59,116.74\left(J_{C F}=2.2 \mathrm{~Hz}\right), 108.83\left(J_{C F}=12.5 \mathrm{~Hz}\right)$, $108.825\left(J_{C F}=26.25 \mathrm{~Hz}\right), 103.41\left(J_{C F}=25.2 \mathrm{~Hz}\right), 73.28,56.39,55.20,46.15,35.17,28.61,19.18$. HRMS (ESI) calculated for $\mathrm{C}_{29} \mathrm{H}_{29} \mathrm{~N}_{5} \mathrm{O}_{2} \mathrm{~F}_{2}$ [M $+\mathrm{HCOO}^{-}: 562.2271$, found: 562.2248 . Purity: $99.4 \%$ (by HPLC). 
5-(3-cyanophenyl)-1-(3-(5-((3-(dimethylamino)propyl)thio)pyrimidin-2-yl)benzyl)-3-fluoropyridin -2(1H)-one (36a). Compound 36a was prepared via a similar procedure of 11a. Yellow solid. m.p. 116.3-117.9 ${ }^{\circ} \mathrm{C}$. Yield: $72 \% .{ }^{1} \mathrm{H}-\mathrm{NMR}\left(400 \mathrm{MHz}, \mathrm{CDCl}_{3}\right) \delta 8.74(\mathrm{~s}, 1 \mathrm{H}), 8.43(\mathrm{~s}, 1 \mathrm{H}), 8.41-8.37(\mathrm{~m}, 1 \mathrm{H})$, $7.64(\mathrm{~s}, 1 \mathrm{H}), 7.62-7.52(\mathrm{~m}, 3 \mathrm{H}), 7.52-7.49(\mathrm{~m}, 2 \mathrm{H}), 7.45-7.41(\mathrm{~m}, 1 \mathrm{H}), 7.37(\mathrm{dd}, J=9.8,2.3 \mathrm{~Hz}, 1 \mathrm{H}), 5.36$ $(\mathrm{s}, 2 \mathrm{H}), 3.03(\mathrm{t}, J=7.2 \mathrm{~Hz}, 2 \mathrm{H}), 2.45(\mathrm{t}, J=7.0 \mathrm{~Hz}, 2 \mathrm{H}), 2.26(\mathrm{~s}, 6 \mathrm{H}), 1.93-1.80(\mathrm{~m}, 2 \mathrm{H}) .{ }^{13} \mathrm{C}-\mathrm{NMR}(126$ $\left.\mathrm{MHz}, \mathrm{CDCl}_{3}\right) \delta 161.35,157.48,155.62\left(J_{C F}=26.25 \mathrm{~Hz}\right), 152.58\left(J_{C F}=251.25 \mathrm{~Hz}\right), 137.92,137.05,135.88$, $131.10,130.72,130.68,130.23,130.16\left(J_{C F}=3.75 \mathrm{~Hz}\right), 130.06,129.66,129.42,128.25,127.85,119.54\left(J_{C F}=\right.$ $17.5 \mathrm{~Hz}), 118.29,116.57\left(J_{C F}=5.0 \mathrm{~Hz}\right), 113.46,57.86,52.50,45.31,31.65,27.03$. HRMS (ESI) calculated for $\mathrm{C}_{28} \mathrm{H}_{26} \mathrm{~N}_{5} \mathrm{OFS}[\mathrm{M}+\mathrm{H}]^{+}: 500.1915$, found: 500.1898 . Purity: $98.1 \%$ (by HPLC).

1-(3-(5-((3-(dimethylamino)propyl)thio)pyrimidin-2-yl)benzyl)-5,5'-difluoro-[3,3'-bipyridin]-6(1H) -one (36b). Compound 36b was prepared via a similar procedure of 11a. White solid. m.p. 128.3-129.9 ${ }^{\circ} \mathrm{C}$. Yield: $75 \% .{ }^{1} \mathrm{H}-\mathrm{NMR}\left(400 \mathrm{MHz}, \mathrm{CDCl}_{3}\right) \delta 8.74(\mathrm{~s}, 2 \mathrm{H}), 8.47-8.36(\mathrm{~m}, 4 \mathrm{H}), 7.51(\mathrm{~d}$, $J=5.1 \mathrm{~Hz}, 2 \mathrm{H}), 7.45-7.42(\mathrm{~m}, 1 \mathrm{H}), 7.40-7.33(\mathrm{~m}, 2 \mathrm{H}), 5.37(\mathrm{~s}, 2 \mathrm{H}), 3.04(\mathrm{t}, J=7.2 \mathrm{~Hz}, 2 \mathrm{H}), 2.44(\mathrm{t}$, $J=7.0 \mathrm{~Hz}, 2 \mathrm{H}), 2.25(\mathrm{~s}, 6 \mathrm{H}), 1.91-1.79(\mathrm{~m}, 2 \mathrm{H}) .{ }^{13} \mathrm{C}-\mathrm{NMR}\left(126 \mathrm{MHz}, \mathrm{CDCl}_{3}\right) \delta 161.29,159.52\left(J_{C F}=\right.$ $257.50 \mathrm{~Hz}), 157.52,157.45,155.59\left(J_{C F}=26.25 \mathrm{~Hz}\right), 152.66\left(J_{C F}=252.50 \mathrm{~Hz}\right), 142.80\left(J_{C F}=3.75 \mathrm{~Hz}\right)$, $137.96,137.20\left(J_{C F}=23.75 \mathrm{~Hz}\right), 135.75,130.77,130.73,130.36\left(J_{C F}=5.0 \mathrm{~Hz}\right), 129.65,128.26,127.88,120.01$ $\left(J_{C F}=18.75 \mathrm{~Hz}\right), 119.33\left(J_{C F}=18.75 \mathrm{~Hz}\right), 113.96\left(J_{C F}=6.25 \mathrm{~Hz}\right), 57.91,52.48,45.40,31.69,27.16$. HRMS (ESI) calculated for $\mathrm{C}_{26} \mathrm{H}_{25} \mathrm{~N}_{5} \mathrm{OF}_{2} \mathrm{~S}[\mathrm{M}+\mathrm{H}]^{+}:$494.1821, found: 494.1807. Purity: 99.7\% (by HPLC).

1-(3-(5-((3-(dimethylamino)propyl)thio)pyrimidin-2-yl)benzyl)-3-fluoro-5-(pyrimidin-5-yl)pyridin -2(1H)-one (36c). Compound 36c was prepared via a similar procedure of 11a. White solid. 128.9-129.8 ${ }^{\circ} \mathrm{C}$. Yield: $78 \% .{ }^{1} \mathrm{H}-\mathrm{NMR}\left(400 \mathrm{MHz}, \mathrm{CDCl}_{3}\right) \delta 9.16(\mathrm{~s}, 1 \mathrm{H}), 8.75(\mathrm{~s}, 2 \mathrm{H}), 8.74(\mathrm{~s}, 2 \mathrm{H})$, 8.45-8.37 (m, 2H), $7.51(\mathrm{~d}, J=5.1 \mathrm{~Hz}, 2 \mathrm{H}), 7.44(\mathrm{~s}, 1 \mathrm{H}), 7.36(\mathrm{dd}, J=9.5,2.3 \mathrm{~Hz}, 1 \mathrm{H}), 5.37(\mathrm{~s}, 2 \mathrm{H}), 3.04(\mathrm{t}$, $J=7.2 \mathrm{~Hz}, 2 \mathrm{H}), 2.45(\mathrm{t}, J=7.0 \mathrm{~Hz}, 2 \mathrm{H}), 2.26(\mathrm{~s}, 6 \mathrm{H}), 1.93-1.80(\mathrm{~m}, 2 \mathrm{H}) .{ }^{13} \mathrm{C}-\mathrm{NMR}\left(126 \mathrm{MHz}, \mathrm{CDCl}_{3}\right)$ $\delta 161.06,157.52,157.25,155.40\left(J_{C F}=25.7 \mathrm{~Hz}\right), 153.68,151.64,137.82,135.46,131.62\left(J_{C F}=10.2 \mathrm{~Hz}\right)$, $130.63,130.16\left(J_{C F}=4.6 \mathrm{~Hz}\right), 129.50,128.71\left(J_{C F}=12.5 \mathrm{~Hz}\right), 128.14,127.73,118.68\left(J_{C F}=18.2 \mathrm{~Hz}\right), 111.65$ $\left(J_{C F}=5.5 \mathrm{~Hz}\right), 57.73,52.35,45.21,31.49,26.96$. HRMS (ESI) calculated for $\mathrm{C}_{25} \mathrm{H}_{25} \mathrm{~N}_{6} \mathrm{OFS}[\mathrm{M}+\mathrm{H}]^{+}$: 477.1867, found: 477.1857. Purity: $98.9 \%$ (by HPLC).

5-(3-cyanophenyl)-1-(1-(3-(5-((3-(dimethylamino)propyl)thio)pyrimidin-2-yl)phenyl)ethyl)-3fluoropyridin-2(1H)-one (39). Compound 39 was prepared via a similar procedure of 11a. Colorless oil. Yield: $82 \% .{ }^{1} \mathrm{H}-\mathrm{NMR}\left(400 \mathrm{MHz}, \mathrm{CDCl}_{3}\right) \delta 8.75(\mathrm{~s}, 2 \mathrm{H}), 8.49(\mathrm{~s}, 1 \mathrm{H}), 8.40(\mathrm{~d}, J=7.6 \mathrm{~Hz}, 1 \mathrm{H}), 7.60-7.43$ $(\mathrm{m}, 6 \mathrm{H}), 7.32(\mathrm{dd}, J=9.8,2.3 \mathrm{~Hz}, 1 \mathrm{H}), 7.22(\mathrm{~s}, 1 \mathrm{H}), 6.62(\mathrm{q}, J=7.0 \mathrm{~Hz}, 1 \mathrm{H}), 3.04(\mathrm{t}, J=7.2 \mathrm{~Hz}, 2 \mathrm{H}), 2.47(\mathrm{t}$, $J=7.0 \mathrm{~Hz}, 2 \mathrm{H}), 2.27(\mathrm{~s}, 6 \mathrm{H}), 1.91-1.81(\mathrm{~m}, 5 \mathrm{H}) .{ }^{13} \mathrm{C}-\mathrm{NMR}\left(101 \mathrm{MHz}, \mathrm{CDCl}_{3}\right) \delta 161.36,157.45,155.42\left(J_{C F}\right.$ $=25.0 \mathrm{~Hz}), 152.15\left(J_{C F}=251.0 \mathrm{~Hz}\right), 139.61,137.97,137.32,130.98,130.76,130.21,130.03,130.01,129.53$, $129.40,128.20,127.26\left(J_{C F}=5.0 \mathrm{~Hz}\right), 126.64,119.00\left(J_{C F}=18.0 \mathrm{~Hz}\right), 118.33,116.57\left(J_{C F}=6.0 \mathrm{~Hz}\right), 113.37$, 57.88, 53.78, 45.34, 31.65, 27.08, 19.23. HRMS (ESI) calculated for $\mathrm{C}_{29} \mathrm{H}_{28} \mathrm{~N}_{5} \mathrm{OFS}[\mathrm{M}+\mathrm{H}]^{+}: 514.2071$, found: 514.2066. Purity: 99\% (by HPLC).

\subsection{Biological Assay}

\subsubsection{Cell lines and Culture}

The cell lines, 97H (human liver cancer cell), Pc9 (human non-small cell lung cancer), HELA (human epithelial cervical cancer cell line), SJSA1 (human osteosarcoma cells), LO2 (human normal liver cells), and HLF (human embryonic lung fibroblast), used in this study were purchased from the Guangzhou ginny ou Biotechnology Co. Ltd. (Guangzhou, China). Cell lines were cultivated in Dulbecco's Modified Eagle Medium (DMEM) containing 10\% $(v / v)$ heat-inactivated fetal bovine serum (FBS), 100 units $/ \mathrm{mL}$ penicillin, and $100 \mu \mathrm{g} / \mathrm{mL}$ streptomycin. 


\subsubsection{Kinase Inhibition Assay.}

The c-Met enzymes and the Z'-LYTE Kinase Kit were purchased from Invitrogen. The tested compounds were used in concentrations of 0.001 to $10 \mathrm{mM}$. Briefly, $1 \mu \mathrm{L}$ of an inhibitor or $5 \%$ DMSO, $2 \mu \mathrm{L}$ of enzyme, and $2 \mu \mathrm{L}$ of substrate/ATP mix were added to a 384-well low volume plate $\mathrm{L}$ and incubated at room temperature for $60 \mathrm{~min}$. Then, $5 \mu \mathrm{L}$ of ADP-Glo ${ }^{\mathrm{TM}}$ Reagent was added, and the mixture was incubated at room temperature for $40 \mathrm{~min}$. Finally, $10 \mu \mathrm{L}$ of Kinase Detection Reagent was added, and the mixture was incubated at room temperature for $30 \mathrm{~min}$. The plate was measured on a multifunction microplate reader (Molecular Devices, Flex Station 3), and the luminescence was recorded (integration time $0.5-1 \mathrm{~s}$ ). Curve fitting and data presentations were performed using Graph Pad Prism version 5.0 (GraphPad Inc., La Jolla, CA, USA). Every experiment was repeated at least three times.

\subsubsection{MTT (Thiazolyl Blue Tetrazolium Bromide) Assay.}

For the cytotoxicity assay, the cells grown in the logarithmic phase were seeded into 96-well plates $\left(5 \times 10^{3}\right.$ cells /well) for $24 \mathrm{~h}$, and then exposed to different concentrations of the test compounds for $48 \mathrm{~h}$. After the attached cells had been incubated with $5 \mathrm{mg} / \mathrm{mL}$ MTT (Sigma, St. Louis, MO, USA) for another $4 \mathrm{~h}$, the suspension was discarded and subsequently the dark blue crystals (formazan) were solubilized in dimethyl sulfoxide (DMSO). Then, the absorbance was measured at $570 \mathrm{~nm}$ using a multifunction microplate reader (Molecular Devices, Flex Station 3) (Thermo Fisher Scientific, San Jose, CA, USA), and each experiment was performed at least in triplicate. The cytotoxic effects of each compound were expressed as the $\mathrm{IC}_{50}$ values, which represents the drug concentration required to cause 50\% tumor cell growth inhibition. This was calculated with GraphPad Prism Software version 5.02 (GraphPad Inc., La Jolla, CA, USA).

\subsubsection{Western Blot Analysis.}

$97 \mathrm{H}$ cells seeded in $60-\mathrm{mm}$ dishes at a density of $5 \times 10^{5}$ cells/well were incubated with or without compound 31e at the indicated concentrations for $4 \mathrm{~h}$. After incubation, the cells were washed twice with ice-cold PBS, and then lysed in RIPA lysis buffer (Radio Immunoprecipitation Assay) containing $150 \mathrm{mM} \mathrm{NaCl}, 50 \mathrm{mM}$ Tris (pH 7.4), 1\% (w/v) sodium deoxycholate, $1 \%(v / v)$ Triton X-100, $0.1 \%(w / v)$ SDS, and $1 \mathrm{mM}$ EDTA (ethylenediaminetetraacetic acid) (Beyotime, Shanghai, China). The lysates were incubated at $0{ }^{\circ} \mathrm{C}$ for $30 \mathrm{~min}$, and vortexed every $10 \mathrm{~min}$ intermittently, then the total proteins were harvested by centrifuging at $12,500 \mathrm{~g}$ for $15 \mathrm{~min}$. The protein concentrations were determined by a BCA (bicinchoninic acid) Protein Assay Kit (Thermo Fisher Scientific, Rockford, IL, USA), and then the protein extracts were reconstituted in loading buffer containing $62 \mathrm{mM}$ Tris- $\mathrm{HCl}$, $2 \%$ SDS (sodium dodecyl sulfate), 10\% glycerol, and 5\% $\beta$-mercaptoethanol (Beyotime, Shanghai, China), and boiled at $100{ }^{\circ} \mathrm{C}$ for $3 \mathrm{~min}$. An equal amount of the proteins (40 $\mu \mathrm{g}$ ) was separated by $8 \%-12 \%$ sodium dodecyl sulphate-polyacrylamide gel electrophoresis (SDS-PAGE) and were transferred to nitrocellulose membranes (Amersham Biosciences, Little Chalfont, Buckinghamshire, UK). After blocking with 5\% non-fat dried milk in TBS containing 1\% Tween-20 for $90 \mathrm{~min}$ at room temperature, the membranes were incubated overnight with specific primary antibodies (Abcam, London, England) at $4{ }^{\circ} \mathrm{C}$. After three washes in TBST, the membranes were incubated with the appropriate HRP-conjugated (Horseradish Peroxidase-conjugated) secondary antibodies at room temperature for $2 \mathrm{~h}$. The blots were developed with enhanced chemiluminescence (Pierce, Rockford, IL, USA) and detected by an LAS4000 imager (GE Healthcare, Waukesha, WI, USA).

\subsubsection{Cell Cycle Analysis}

$97 \mathrm{H}$ cells were seeded in 6-well plates $\left(3 \times 10^{5}\right.$ cells/well) and incubated in the presence or absence of compound 31e at the indicated concentrations for $24 \mathrm{~h}$. Then, cells were harvested by centrifugation and fixed in 70\% ice-cold ethanol overnight. The ethanol was removed the next day, 
and then the cells were resuspended in the ice-cold PBS and treated with RNAse A (Keygen Biotech, Nanjing, China) at $37^{\circ} \mathrm{C}$ for $30 \mathrm{~min}$, followed by incubation with the DNA staining solution propidium iodide (PI) (Keygen Biotech, Nanjing, China) at $4{ }^{\circ} \mathrm{C}$ for $30 \mathrm{~min}$. About 10,000 events were detected by flow cytometry (Epics XL, Beckman Coulter, Fullerton, CA, USA) at $488 \mathrm{~nm}$. The data regarding the number of cells in different phases of the cell cycle were analyzed by EXPO32 ADC analysis software (Beckman Coulter, Fullerton, CA, USA).

\subsubsection{Anti-Cell-Migration Study}

97H cells were plated in a 6-well culture dish at $5 \times 10^{4}$ cells / dish and grown for $24 \mathrm{~h}$, and the non-migrated cells were scraped off the upper surface of the membrane with a $10 \mu \mathrm{L}$ pipette. The medium was then replaced with 10\% serum DMEM medium and treated with compound 31e at the indicated concentrations for another $36 \mathrm{~h}$. After washing with phosphate buffer solution (PBS), the cell images were immediately detected by a Zeiss LSM 570 laser scanning confocal microscope (Carl Zeiss, Jena, Germany).

\section{Conclusions}

We synthesized a series of new Tepotinib derivatives to evaluate their ability to act as antiproliferative agents. The optimal compound, 31e, in which pyridazinone is replaced with the pyrimidin-2(1H)-one moiety and methyl substitution on the methylene moiety of Tepotinib is introduced, exhibited potent antiproliferative activity $\left(\mathrm{IC}_{50}: 0.026 \mu \mathrm{M}\right)$ against hepatic carcinoma $97 \mathrm{H}$ cells. The mechanism study indicated that 31e induces G1 phase arrest and inhibits the phosphorylation of c-Met and its downstream signaling component, Akt, in a dose-dependent manner. Overall, the current study demonstrates that 31e is a promising leading compound in the development of anticancer agents. Further structural optimization and the evaluation of its in vivo anti-tumor activity are in progress.

Supplementary Materials: The spectra of ${ }^{1} \mathrm{H}-\mathrm{NMR}$ and ${ }^{13} \mathrm{C}-\mathrm{NMR}$ for the target compounds are available online. Author Contributions: Project administration, N.-n.Z., B.-j.A., Y.Z. and X.-s.L.; Writing-original draft, N.-n.Z. and X.-s.L.; Writing-review \& editing, X.-s.L. and M.Y.

Funding: This research was funded by the National Natural Science Foundation of China (No. 21772240), the Guangzhou Science Technology and Innovation Commission (201707010210).

Conflicts of Interest: The authors declare no conflict of interest.

\section{References}

1. World Health Organization. Available online: https://www.who.int/cancer/en/ (accessed on 20 March 2019).

2. Bottaro, D.P.; Rubin, J.S.; Faletto, D.L.; Chan, A.M.L.; Kmiecik, T.E.; Vandewoude, G.F.; Aaronson, S.A. Identification of the hepatocyte growth factor receptor as the c-met proto-oncogene product. Science 1991, 251, 802-804. [CrossRef] [PubMed]

3. Blumejensen, P.; Hunter, T. Oncogenic kinase signaling. Nature 2001, 411, 355-365. [CrossRef] [PubMed]

4. Gherardi, E.; Birchmeier, W.; Birchmeier, C.; Woude, G.V. Targeting MET in cancer: Rationale and progress. Nat. Rev. Cancer 2012, 12, 89. [CrossRef] [PubMed]

5. Goyal, L.; Muzumdar, M.D.; Zhu, A.X. Targeting the HGF/c-MET pathway in hepatocellular carcinoma. Clin. Cancer Res. 2013, 19, 2310. [CrossRef] [PubMed]

6. Turke, A.B.; Zejnullahu, K.; Wu, Y.L.; Song, Y.; Dias-Santagata, D.; Lifshits, E.; Toschi, L.; Rogers, A.; Mok, T.; Sequist, L.; et al. Preexistence and clonal selection of MET amplification in EGFR mutant NSCLC. Cancer Cell 2010, 17, 77. [CrossRef] [PubMed]

7. Otsuka, T.; Takayama, H.; Sharp, R.; Celli, G.; LaRochelle, W.J.; Bottaro, D.P.; Ellmore, N.; Vieira, W.; Owens, J.W.; Anver, M.; et al. C-Met autocrine activation induces development of malignant melanoma and acquisition of the metastatic phenotype. Cancer Res. 1998, 58, 5157-5167. [PubMed] 
8. Umeki, K.; Shiota, G.; Kawasaki, H. Clinical Significance of c-met Oncogene Alterations in Human Colorectal Cancer. Oncology 1999, 56, 314-321. [CrossRef] [PubMed]

9. Comoglio, P.M.; Trusolino, L. Series Introduction: Invasive growth: From development to metastasis. J. Clin. Invest. 2002, 109, 857-862. [CrossRef] [PubMed]

10. Comoglio, P.M.; Giordano, S.; Trusolino, L. Drug development of MET inhibitors: Targeting oncogene addiction and expedience. Nat. Rev. Drug Discov. 2008, 7, 504-516. [CrossRef] [PubMed]

11. Zou, H.Y.; Li, Q.; Lee, J.H.; Arango, M.E.; McDonnell, S.R.; Yamazaki, S.; Koudriakova, T.B.; Alton, G.; Cui, J.J.; Kung, P.P.; et al. An orally available small-molecule inhibitor of c-Met, PF-2341066, exhibits cytoreductive antitumor efficacy through antiproliferative and antiangiogenic mechanisms. Cancer Res. 2007, 67, 4408-4417. [CrossRef] [PubMed]

12. Cui, J.J.; Tran-Dube, M.; Shen, H.; Nambu, M.; Kung, P.P.; Pairish, M.; Jia, L.; Meng, J.; Funk, L.; Botrous, I.; et al. Structure based drug design of crizotinib (PF-02341066), a potent and selective dual inhibitor of mesenchymal-epithelial transition factor (c-MET) kinase and anaplastic lymphoma kinase (ALK). J. Med. Chem. 2011, 54, 6342-6363. [CrossRef] [PubMed]

13. Atreya, C.E.; Song, E.K.; Messersmith, W.; Purkey, A.; Bagby, S.; Quackenbush, K.; Kelley, R.K.; Kwak, E.; Ryan, D.; Venook, A.; et al. Abstract LB-302: Potent antitumor activity of XL184 (cabozantinib), a c-MET and VEGFR2 inhibitor, in colorectal cancer patient-derived tumor explant models. J. Cancer Res. 2013, 73, 1967-1975. [CrossRef]

14. Munshi, N.; Jeay, S.; Li, Y.Z.; Chen, C.R.; France, D.S.; Ashwell, M.A.; Hill, J.; Moussa, M.M.; Leggett, D.S.; $\mathrm{Li}, \mathrm{C}$. ARQ 197, a novel and selective inhibitor of the human c-Met receptor tyrosine kinase with antitumor activity. J. Mol. Cancer Ther. 2010, 9, 1544-1553. [CrossRef] [PubMed]

15. Dorsch, D.; Schadt, O.; Stieber, F.; Meyring, M.; Grädler, U.; Bladt, F.; Friese-Hamim, M.; Knühl, C.; Pehl, U.; Blaukat, A. Identification and optimization of pyridazinones as potent and selective c-Met kinase inhibitors. Biorgan. Med. Chem. Lett. 2015, 25, 1597-1602. [CrossRef] [PubMed]

16. Parikh, P.K.; Ghate, M.D. Recent advances in the discovery of small molecule c-Met kinase inhibitors. Eur. J. Med. Chem. 2017, 143, 1103-1138. [CrossRef] [PubMed]

17. Mukaiyama, H.; Nishimura, T.; Kobayashi, S.; Ozawa, T.; Kamada, N.; Komatsu, Y.; Kikuchi, S.; Oonota, H.; Kusama, H. Synthesis and c-Src inhibitory activity of imidazo $[1,5-a]$ pyrazine derivatives as an agent for treatment of acute ischemic stroke. Biorgan. Med. Chem. 2007, 15, 868-885. [CrossRef] [PubMed]

18. Lu, Y.H.; Zhao, Y.Q.; Wang, S.C.; Wang, X.; Ge, Z.M.; Li, R.T. An efficient synthesis of 2-thio-5-amino substituted benzoquinones via KI catalyzed cascade oxidation/michael addition/oxidation starting from hydroquinone. RSC Adv. 2016, 6, 11378-11381. [CrossRef]

19. Nagase, T.; Mizutani, T.; Ishikawa, S.; Sekino, E.; Sasaki, T.; Fujimura, T.; Ito, S.; Mitobe, Y.; Miyamoto, Y.; Yoshimoto, R.; et al. Synthesis, structure-activity relationships, and biological Profiles of a quinazolinone class of histamine H3 receptor inverse agonists. J. Med. Chem. 2008, 51, 4780-4789. [CrossRef] [PubMed]

Sample Availability: Samples of the compounds are available from the authors.

(C) 2019 by the authors. Licensee MDPI, Basel, Switzerland. This article is an open access article distributed under the terms and conditions of the Creative Commons Attribution (CC BY) license (http:/ / creativecommons.org/licenses/by/4.0/). 